\title{
Impacts of land-use history on the recovery of ecosystems after agricultural abandonment
}

\author{
Andreas Krause $^{1}$, Thomas A. M. Pugh ${ }^{1,2}$, Anita D. Bayer ${ }^{1}$, Mats Lindeskog ${ }^{3}$, and Almut Arneth ${ }^{1}$ \\ ${ }^{1}$ Karlsruhe Institute of Technology, Institute of Meteorology and Climate Research - Atmospheric \\ Environmental Research (IMK-IFU), Kreuzeckbahnstr. 19, 82467 Garmisch-Partenkirchen, Germany \\ ${ }^{2}$ School of Geography, Earth \& Environmental Science and Birmingham Institute of Forest Research, \\ University of Birmingham, Birmingham, B15 2TT, UK \\ ${ }^{3}$ Department of Physical Geography and Ecosystem Science, Lund University, 22362 Lund, Sweden
}

Correspondence to: Andreas Krause (andreas.krause@ kit.edu)

Received: 16 March 2016 - Published in Earth Syst. Dynam. Discuss.: 14 April 2016

Revised: 26 August 2016 - Accepted: 29 August 2016 - Published: 15 September 2016

\begin{abstract}
Land-use changes have been shown to have large effects on climate and biogeochemical cycles, but so far most studies have focused on the effects of conversion of natural vegetation to croplands and pastures. By contrast, relatively little is known about the long-term influence of past agriculture on vegetation regrowth and carbon sequestration following land abandonment. We used the LPJ-GUESS dynamic vegetation model to study the legacy effects of different land-use histories (in terms of type and duration) across a range of ecosystems. To this end, we performed six idealized simulations for Europe and Africa in which we made a transition from natural vegetation to either pasture or cropland, followed by a transition back to natural vegetation after 20 , 60 or 100 years. The simulations identified substantial differences in recovery trajectories of four key variables (vegetation composition, vegetation carbon, soil carbon, net biome productivity) after agricultural cessation. Vegetation carbon and composition typically recovered faster than soil carbon in subtropical, temperate and boreal regions, and vice versa in the tropics. While the effects of different land-use histories on recovery periods of soil carbon stocks often differed by centuries across our simulations, differences in recovery times across simulations were typically small for net biome productivity (a few decades) and modest for vegetation carbon and composition (several decades). Spatially, we found the greatest sensitivity of recovery times to prior land use in boreal forests and subtropical grasslands, where post-agricultural productivity was strongly affected by prior land management. Our results suggest that land-use history is a relevant factor affecting ecosystems long after agricultural cessation, and it should be considered not only when assessing historical or future changes in simulations of the terrestrial carbon cycle but also when establishing long-term monitoring networks and interpreting data derived therefrom, including analysis of a broad range of ecosystem properties or local climate effects related to land cover changes.
\end{abstract}

\section{Introduction}

Historically, many natural forests or grasslands on Earth have been cleared or cultivated for grazing, timber, food production, mining or settlements. However, land-use change (LUC) in these areas has rarely been continuous, and land cover and management have often changed for a variety of reasons (Burgi and Turner, 2002). Based on the HYDE dataset, Campbell et al. (2008) estimated that 269 Mha of cropland and 479 Mha of pasture have been abandoned between 1700 and 2000. Recently, agricultural cessation rates have risen globally, especially in the temperate region. For example, during the last decades, large areas in Europe previously used for pasture or crop cultivation have been abandoned (e.g., Schierhorn et al., 2013; Smith et al., 2005). Following agricultural abandonment, and in the absence of fur- 
ther anthropogenic influence, natural vegetation recolonizes in a typical succession from herbaceous vegetation to shrubland and forests, if environmental conditions are suitable for tree growth. These secondary forests act as an important carbon (C) sink during the years of regrowth, thereby reducing the growth rate of global atmospheric $\mathrm{CO}_{2}$ concentration (Pan et al., 2011).

The immediate effects of land-use (LU) practices on $\mathrm{C}$ fluxes and nutrient cycles have been studied in some detail over recent decades. Generally, agriculture significantly reduces $\mathrm{C}$ and, in the absence of supplementary sources, nitrogen $(\mathrm{N})$ pools due to initial deforestation, reduced soil litter input, and accelerated soil decomposition and erosion (Davidson and Ackerman, 1993; Fujisaki et al., 2015; Guo and Gifford, 2002; McLauchlan, 2006; Murty et al., 2002). Pasture soils can be an exception as they have been found to accumulate $\mathrm{C}$, depending on location and management (McSherry and Ritchie, 2013; Milchunas and Lauenroth, 1993). The long-term importance of past LU on ecosystems, however, was recognized only recently, and much less effort has been put so far into the investigation of legacy effects of LU history on ecosystem processes, how long these effects persist, or whether they may even be irreversible (Chazdon, 2014; Compton and Boone, 2000; Cramer et al., 2008; Hobbs et al., 2009; McLauchlan, 2006). This is important not only for understanding present-day ecological systems but also because, due to demographical, social, technological, economic and environmental changes, LUC and land abandonment will continue to occur in the future (Hurtt et al., 2011).

Most observational studies that looked at the recovery of ecosystems after agricultural cessation focused on the first years of succession. Analyses of the long-term effects of historical LU are often limited by the availability of adequate LU information and the absence of undisturbed ecosystems, and usually rely on chronosequences (Chazdon, 2003; Knops and Tilman, 2000). Only a few long-term observational study plots like the one maintained at the Rothamsted Experimental Station (e.g., Poulton et al., 2003) exist. Differences between (near) pristine and post-agricultural forests or grasslands have been reported to persist for decades or centuries after agricultural abandonment for various variables, including soil pH (Falkengren-Grerup et al., 2006); microbial communities (Fichtner et al., 2014); soil C, N and phosphorus (Compton and Boone, 2000); and other nutrients (Wall and Hytonen, 2005). Furthermore, aboveground (ag) biomass (Wandelli and Fearnside, 2015), percentage vegetation cover (Lesschen et al., 2008), biodiversity (Vellend, 2004), species composition (Aide et al., 2000) and structure (Bellemare et al., 2002) remained affected for years to decades, or even longer. These effects have consequences, not only for the $\mathrm{C}$ sink capacity of the ecosystem but also for water and energy exchange between the land and the atmosphere (Foley et al., 2003), which also has important, albeit still highly uncertain, implications for regional climate change (e.g., Arora and Montenegro, 2011; Brovkin et al., 2013; de Noblet-
Ducoudre et al., 2012). Some studies have detected an influence of ancient agriculture on forest composition and diversity even thousands of years later (Dambrine et al., 2007; Dupouey et al., 2002; Willis et al., 2004). However, the persistence of legacy effects varies considerably with former LU, geographical location, sampling methods and examined variables, making recovery trajectories often hard to predict (Cramer et al., 2008; Foster et al., 2003; Guariguata and Ostertag, 2001; Norden et al., 2015; Post and Kwon, 2000; Suding et al., 2004).

In this study, we performed idealized simulations with the LPJ-GUESS dynamic global vegetation model (DGVM) to explore the importance of agricultural LU history in terms of type and duration for the regeneration of ecosystems and $\mathrm{C}$ stocks and fluxes under a range of environmental conditions. We converted natural vegetation to either pasture or cropland, followed by a re-transition to natural vegetation after time periods of 20,60 and 100 years. While there are numerous variables suitable to measure recovery (Chazdon, 2003; Martin et al., 2016), we analyzed recovery times for vegetation composition (represented here by the dominant plant functional type), vegetation $\mathrm{C}$, soil $\mathrm{C}$, and net biome productivity to evaluate the longevity of the effects of LU history on the $\mathrm{C}$ cycle component of ecosystems and to ascertain whether the system eventually recovers to its pre-disturbance state.

\section{Methods}

\subsection{LPJ-GUESS}

LPJ-GUESS is a process-based DGVM that is driven by climate, atmospheric $\mathrm{CO}_{2}$ concentration and $\mathrm{N}$ input (Smith et al., 2014). Plants are attributed to one of 11 plant functional types (PFTs, nine groups of tree species and two grasses) which are distinguished, for instance, in terms of their climate preferences for establishment and survival, photosynthetic pathways, growth rates, and growth strategies (see Table A1 for PFT acronyms and names). Vegetation dynamics and composition at a given location result from competition between plants for light and soil resources in a number of independent replicate patches (50 in this study), averaged per $0.5^{\circ} \times 0.5^{\circ}$ grid cell. Wildfire is included in the model and, additionally, stochastic disturbances kill all the biomass in a patch, representing, for example, storm or insect damages, with a typical return period of 100 years (Smith et al., 2014). Recent model updates include the representation of LUC (Lindeskog et al., 2013) and the implementation of the $\mathrm{N}$ cycle in natural vegetation and grasses (Smith et al., 2014). The representation of the $\mathrm{N}$ cycle is crucial for this study because previous agricultural $\mathrm{N}$ dynamics, such as extraction through harvest and input through fertilization, can greatly affect ecosystems even after many decades (Richter et al., 2000). 
Conversion of natural to managed land in LPJ-GUESS is characterized by the initial killing of all living vegetation in the affected area. The corresponding woody biomass is partly oxidized immediately $(67-76 \%)$ and partly transferred to the product $(21 \%)$ or litter $(3-12 \%)$ pool. Ten percent of the leaves are oxidized, while the rest of the leaves and the fine roots enter the litter pool. Only the litter thus remains in the ecosystem subsequent to land conversion. Pastures are represented by preventing tree establishment and wildfires and by splitting the aboveground biomass of the grasses equally between atmosphere (harvest) and litter at the end of each year. Crops were represented by grass PFTs modified to mimic aspects of cropland important for the $\mathrm{C}$ and $\mathrm{N}$ cycles. Settings for croplands and pastures were as follows:

1. For transitions from natural vegetation to cropland, we transferred only $3 \%$ of the cleared woody biomass to the litter instead of $12 \%$ for natural vegetation-pasture transitions. This accounts for the practice that farmers would try to remove as many coarse roots as possible before planting of crops.

2. Harvest efficiency (in this study: fraction of aboveground biomass that is oxidized) was $0.5 \mathrm{yr}^{-1}$ for pasture, representing the net effect of grazing processes (Lindeskog et al., 2013). For crop simulations we changed the harvest efficiency to $0.8 \mathrm{yr}^{-1}$, representing simplified crop harvest, as in Lindeskog et al. (2013).

3. While we removed $100 \%$ of harvested $\mathrm{N}$ biomass for croplands, we changed this value to $65 \%$ for pastures. That accounts for significant urine $\mathrm{N}$ regain from animals fed on pastures (Dean et al., 1975; Lauenroth and Milchunas, 1992).

4. Root turnover rate was $0.7 \mathrm{yr}^{-1}$ for pasture and was adapted to $1.0 \mathrm{yr}^{-1}$ for croplands to represent the annual plant types used in most croplands.

5. In croplands we estimated tillage effects by increasing heterotrophic respiration by a factor of 1.94 (Pugh et al., 2015).

6. We simulated $\mathrm{N}$ fertilization in croplands by applying $75 \mathrm{~kg} \mathrm{ha}^{-1} \mathrm{yr}^{-1}$ equally throughout the year to sustain crop productivity with time. This value represents a compromise between higher values presently found in parts of Europe and lower values in most of Africa (e.g., Potter et al., 2010).

After patch-destroying disturbances or managed land converting back to natural vegetation, there is a typical succession from grasses to light-demanding pioneer trees, eventually followed in many ecosystems by the establishment of shade-tolerant PFTs. It has been shown that LPJ-GUESS is able to realistically simulate observed succession pathways and species variations (Hickler et al., 2004; Smith et al., 2014).

\subsection{Simulation setup}

During spin-up (500 years) and the simulation period (900 years), we forced LPJ-GUESS with temperaturedetrended, repeated 1981-2000 climate from the University of East Anglia Climate Research Unit 3.21 dataset (CRU, 2013), 1990s mean N deposition (Lamarque et al., 2013) and a fixed atmospheric $\mathrm{CO}_{2}$ mixing ratio of $356 \mathrm{ppmv}$. We ran the model for Europe and Africa $\left(33^{\circ} \mathrm{E}\right.$ to $\left.55^{\circ} \mathrm{W}\right)$, covering a wide range of environmental conditions. These regions include all major biomes (Smith et al., 2014). We chose Africa and Europe for the simulation domain because the original LU version of the model was evaluated against observations in Africa (Lindeskog et al., 2013) and to limit the computational expense of the simulations. We did not intend to realistically represent typical crop and pasture management across the domain (i.e., the spatial variability in fertilizer use, multiple cropping systems, or irrigation). For all simulations we used potential natural vegetation cover to spin up the model, followed by a transition to either pasture or croplands directly after spin-up and a transition back to natural vegetation after time periods of 20,60 and 100 years. This resulted in three pasture (P20, P60, P100) and three cropland (C20, C60, C100) simulations. Additionally, we performed a reference simulation in which natural vegetation was retained throughout the whole simulation period.

\subsection{Analyzed grid cells and biome classification}

To facilitate the interpretation, we classified each grid cell to one biome. We used the same classification rules as Smith et al. (2014), aggregated to eight biomes as in Bayer et al. (2015). Afterwards, we excluded grid cells from the analyses which were classified as desert or tundra, had a mean net primary productivity (NPP) below $0.1 \mathrm{~kg} \mathrm{C} \mathrm{m}^{-2} \mathrm{yr}^{-1}$, or were located above $62.5^{\circ} \mathrm{N}$, making the assumption that the relevance of these low-production areas for agriculture is negligible.

\subsection{Analyzed variables and definition of recovery}

We studied the influence of LU history on ecosystems by analyzing four key variables: dominant PFT, vegetation $C$, soil $\mathrm{C}$ (excluding litter) and net biome productivity (NBP). NBP is the net atmosphere-land carbon flux after C losses associated with respiratory fluxes, fire, harvest, land clearing and decomposition of LUC product pools are subtracted from gross primary productivity. We investigated the legacy effects of LU history by calculating a recovery time for each variable, simulation and grid cell after the conversion back to natural vegetation. For vegetation $\mathrm{C}$, soil $\mathrm{C}$ and NBP, recovery time was defined as the year in which the 20 -year running mean of the variable exceeded the threshold of one standard deviation $(\sigma)$ below the mean of the reference simulation (full simulation period) for the first time after agricultural abandonment. $\sigma$ was calculated on the 20-year running 
mean of the reference simulation. To avoid "false-positive" identifications of recovery in cases for which the variable of interest was initially within $1 \sigma$ but then exhibited dynamics taking it outside this range (e.g., soil C in Fig. A1), we applied an additional criterion of whether the minimum after the transition to natural vegetation occurred in the first 200 years and if it was below the mean minus $1 \sigma$ threshold. If that was the case, the condition was expanded so that the variable could only be defined as recovered after the year in which the minimum occurred ("minimum rule"). A 200-year window was chosen because the minimum occurred within the first 200 years for all biome averages of all variables and simulations. If the minimum was located after 200 years, we assumed the minimum to be a result of natural variability and recovery was achieved as soon as the variable in question exceeded the threshold of $1 \sigma$ below the reference mean. Figure A1 shows an example of how soil C recovery was calculated for one site.

For the dominant PFT recovery, we first identified which PFT dominates each grid cell in the reference simulation based on the annual maximum leaf area index (LAI) amongst PFTs. We then checked for dominant PFT recovery in the same way as we did for vegetation $\mathrm{C}$, soil $\mathrm{C}$ and NBP (i.e., whether its LAI exceeded the threshold of $1 \sigma$ below the reference simulation mean; condition 1) but additionally checked whether its LAI was also larger than the LAI of any other PFT in the same simulation and year (i.e., the dominant PFT is the same as in the reference simulation, condition 2). Thus, dominant PFT recovery was only possible if both conditions were fulfilled. For example, if the temperate broadleaved evergreen (TeBS) tree was the dominant PFT in the reference simulation (with an average maximum LAI of, for example, 3.0 and standard deviation of \pm 0.2 ), dominant PFT recovery in a specific LU simulation (e.g., P20) would occur once the LAI of TeBS in this simulation (a) hits the threshold of $2.8(3.0-0.2$, condition 1$)$ and (b) is larger than the LAI of any other PFT in P20 in the specific year i.e., TeBS is the dominant PFT in the grid cell (condition 2). For all variables, the recovery time was capped at 800 years after reconversion to natural vegetation, the point when simulations ended. Recovery times of 800 years thus represent a lower limit. However, the actual recovery time in these cases could theoretically lie between 801 years and infinity.

\section{Results}

\subsection{Reference simulation}

Maps of simulated vegetation and soil C, as well as dominant PFT and biomes derived from PFT composition for the reference simulation, are shown in Fig. 1. The salient features of biome and $\mathrm{C}$ storage distribution at the regional scale are captured (Haxeltine and Prentice, 1996; Scharlemann et al., 2014). Vegetation $C$ reaches its highest values in tropical forests of central Africa and decreases towards the deserts of southern and northern Africa. Patterns are more homogeneous in Europe, where most areas store $5-10 \mathrm{~kg} \mathrm{C} \mathrm{m}^{-2}$. Similar to vegetation $\mathrm{C}$, soil $\mathrm{C}$ in the (sub)tropics also decreases with drier conditions; however, the differences are small, with typical values of $5-10 \mathrm{~kg} \mathrm{C} \mathrm{m}^{-2}$. Soils in the temperate and southern boreal ecosystems of Europe generally store more $\mathrm{C}$ (usually $>10 \mathrm{~kg} \mathrm{C} \mathrm{m}^{-2}$ ), especially in colder environments. While Europe is mostly dominated by woody PFTs (e.g., TeBS is the acronym for temperate broadleaved summergreen tree), in Africa there is a shift from $\mathrm{C}_{3}$ and $\mathrm{C}_{4}$ grasses in the dry regions to trees in the humid tropics. This gradient also appears in the corresponding biome map: in Africa and the Arabian Peninsula, LPJGUESS reproduces the transition from grasslands to savannas and tropical forests ( $\mathrm{TrFo}$ ) as the Equator is approached. Europe is mostly classified as temperate forests (TeFo), with some boreal forests $(\mathrm{BoFo})$ in the north and some shrublands/savannas in the south.

\subsection{Dominant PFT recovery}

The LAI of the dominant PFT recovers on average within around one century for all LU histories (Fig. 2). Maps of the recovery time (Fig. 3) show distinct geographical patterns which occur in all simulations. Most subtropical grasslands and savannas, and parts of the temperate and boreal forests, recover within several decades, some grasslands even within 5 years. In contrast, recovery times are clearly longer ( $>100$ years) in other parts of the temperate forests and in the tropical forests. Long recovery is associated with woody successional vegetation dynamics, as slow-recovering areas are usually dominated by temperate broadleaved summergreen and tropical broadleaved evergreen forests (compare PFT distribution in Fig. 1). These are shade-tolerant PFTs that establish only slowly after disturbances. For $84 \%$ of all analyzed grid cells, condition 1 (LAI recovery) was the delaying condition for dominant PFT recovery (numbers exemplified for the P60 simulation), compared to only $3 \%$ for condition 2 (dominance recovery). For the remaining grid cells, both conditions were fulfilled in the same year.

Overall, differences across simulations of different LU histories are moderate, with generally only small differences in temperate forests, savannas and shrublands (Fig. 3; see also biome averages in Table 1 and the histogram in Fig. A2). Areas of major differences are central Africa, where P20 recovers faster than other simulations because post-agricultural net mineralization rates are higher in this region for P20 than for the other simulations (Fig. 4), thereby relatively increasing post-agricultural $\mathrm{N}$ availability compared to the other simulations (Fig. 5), and the African Mediterranean coast, where croplands recover much faster because the reduced $\mathrm{C}: \mathrm{N}$ ratio in the soil (not shown) enhances $\mathrm{N}$ mineralization and thus plant $\mathrm{N}$ availability compared to pastures. Furthermore, in parts of the boreal zone recovery takes several hundred years for C100 instead of a few decades for the other sim- 


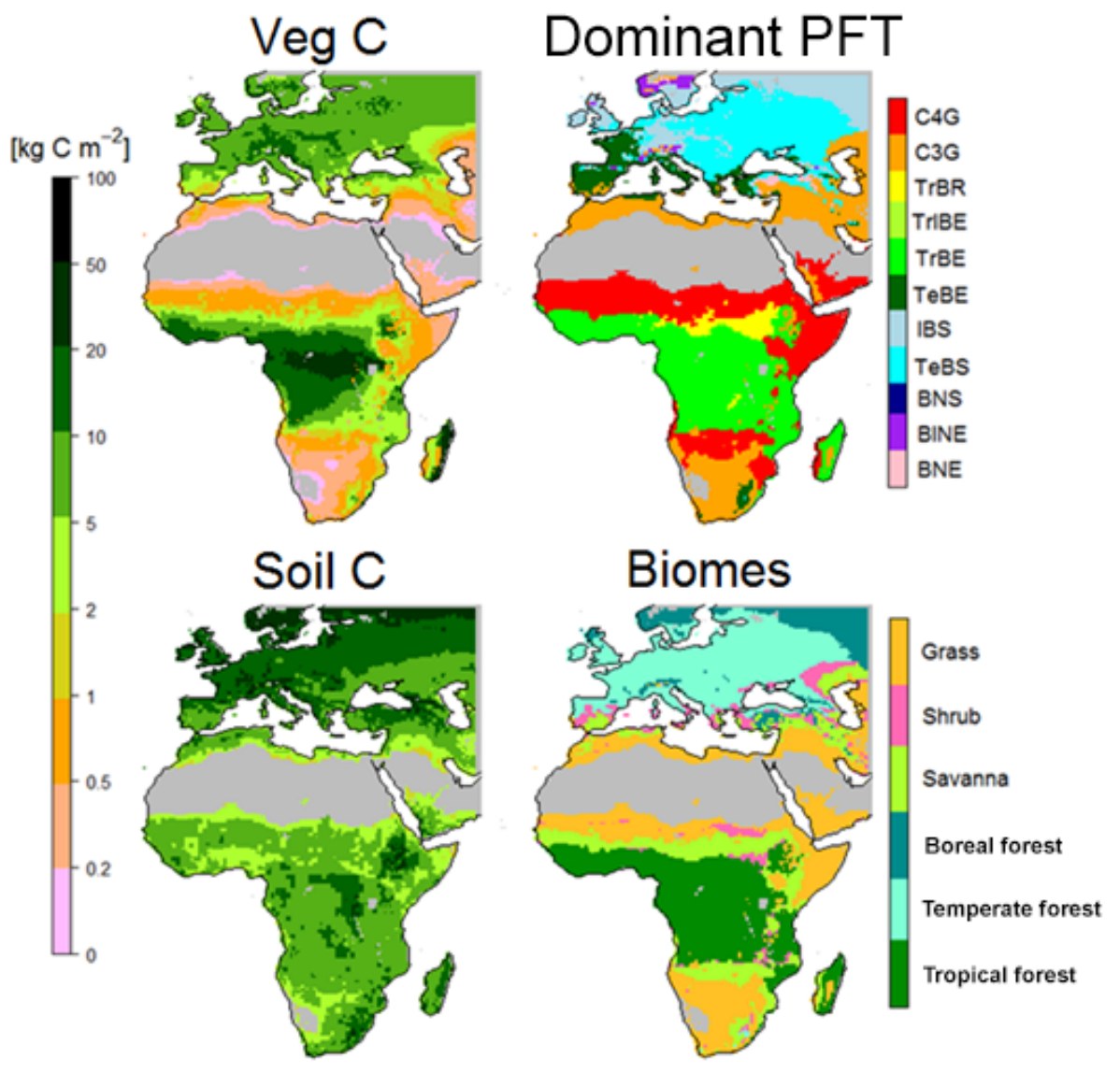

Figure 1. Vegetation $\mathrm{C}\left(\mathrm{kg} \mathrm{C} \mathrm{m}^{-2}\right)$ for the reference simulation, averaged over the whole simulation period of 900 years (upper left panel), soil $\mathrm{C}\left(\mathrm{kg} \mathrm{C} \mathrm{m}^{-2}\right)$ (lower left panel), dominant PFT (upper right panel), and corresponding biomes (lower right panel). Grid cells with a NPP below $0.1 \mathrm{~kg} \mathrm{C} \mathrm{m}^{-2} \mathrm{yr}^{-1}$, deserts and tundra, and latitudes above $62.5^{\circ} \mathrm{N}$ are masked in grey. PFT abbreviations are given in Table A1.

ulations because lower available $\mathrm{N}$ levels relatively reduce the growth of IBS (the dominant PFT in this region) compared to other woody PFTs. Figure 6 shows the maximum differences between recovery times across all simulations per biome (black dots), as well as across a subset of simulations (colored squares and triangles). The differences were first calculated for each grid cell and only then averaged over biomes, thereby providing an estimate of the relative importance of former LU duration versus former LU type on recovery times. While substantial differences occur across the pasture simulations (P20, P60, P100) in tropical forests, savannas and grasslands, and across cropland simulations (C20, $\mathrm{C} 60, \mathrm{C} 100$ ) in boreal forests (emphasizing the importance of LU duration in these regions), major differences between P100 and C100 occur in boreal forests and grasslands (emphasizing the importance of LU type if agricultural duration was long). On the other hand, in our simulations, dominant PFT recovery in temperate forests is hardly influenced by the type of former LU or, conversely, pasture duration has negligible effects on boreal forest recovery. Interestingly, temperate forests recover faster for $\mathrm{P} 100$ and $\mathrm{C} 100$ then for P20 and
C20. This pattern is generally restricted to areas where the TeBS PFT dominates. We interpret this behavior as reduced soil $\mathrm{N}$ favoring TeBS in the competition with other tree PFTs, thereby reaching its background LAI levels earlier.

\subsection{Vegetation C recovery}

Compared to dominant PFT, recovery occurs slightly later for vegetation C (Fig. 2, Table 1). Spatial patterns look more homogeneous than for the dominant PFT (Fig. 3). While most grasslands recover within a few decades for all simulations, in particular so for post-cropland recovery, recovery occurs only after several decades or centuries in forest ecosystems. Lower standard deviations for the mean differences in vegetation $\mathrm{C}$ recovery times compared to the standard deviations for the mean differences in dominant PFT recovery times for most biomes (Fig. 6a and b) reflect the spatially more uniform response of vegetation $\mathrm{C}$ recovery. Exceptions are tropical forests and grasslands, where the standard deviation is higher for vegetation $\mathrm{C}$ recovery compared to dominant PFT recovery. 

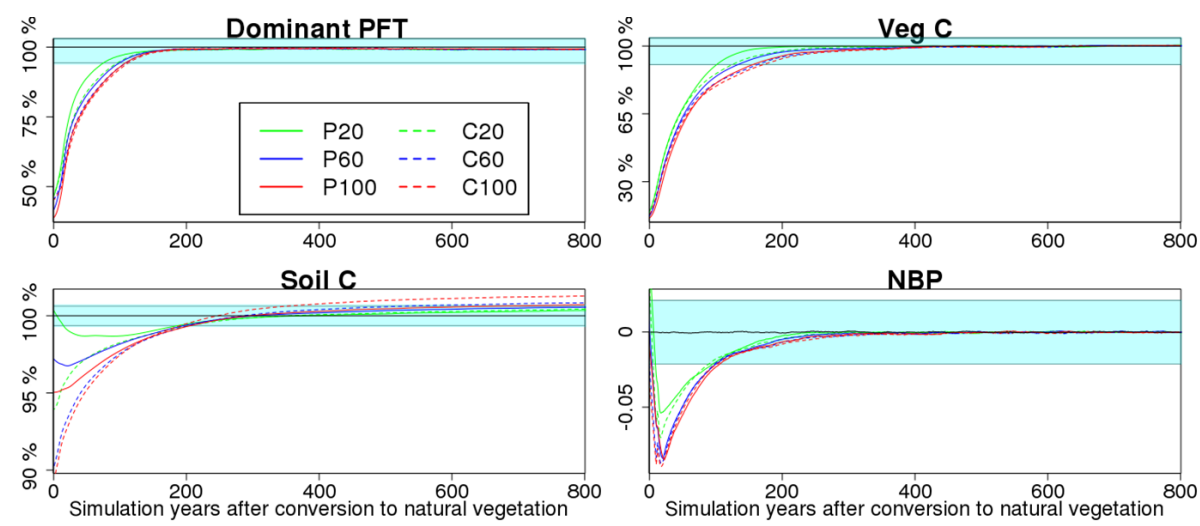

Figure 2. Time series (20-year running mean) of dominant PFT, vegetation C, soil C and NBP for the different experiments, starting from the time of reconversion to natural vegetation and area-averaged over all grid cells. Dominant PFT, vegetation $\mathrm{C}$ and soil $\mathrm{C}$ are shown in relative values compared to reference simulation mean, while NBP is shown as absolute values $\left(\mathrm{kg} \mathrm{C} \mathrm{m}^{-2} \mathrm{yr}^{-1}\right)$ because values cannot be presented relative to a zero background. The cyan-shaded area corresponds to reference simulation mean $\pm 1 \sigma$. Note the different scales on the $y$ axes.

Significant differences in recovery times occur between simulations of different LU types that have the same duration, and between simulations of the same LU type but with different duration. For example, in the grasslands and savannas of southern, eastern and northern Africa, former croplands recover much faster than former pastures (see also Table 1 and Fig. A2) because post-agricultural $\mathrm{N}$ availability is enhanced in these regions (Fig. 5). In former croplands in these environments, the combined effect of fertilizing and harvest is a net $\mathrm{N}$ flux to the ecosystem (not shown) and mineralization rates are enhanced after cropland abandonment (Fig. 4). This net $\mathrm{N}$ flux can partially be explained by high levels of water stress in these savannas and grasslands, resulting in greater $\mathrm{C}$ and $\mathrm{N}$ allocation to roots relative to leaves and thereby decreased harvest removal in this region (Fig. A3). Conversely, recovery in northern European forests is delayed for C60 and, to an even greater extent, $\mathrm{C} 100$ because in this region $\mathrm{N}$ removal by annual harvest exceeds $\mathrm{N}$ addition through fertilization during the agricultural period (not shown) and post-agricultural $\mathrm{N}$ mineralization rates in this region are substantially reduced compared to the other simulations many decades or even a few centuries after abandonment (Fig. 4). Differences in vegetation recovery times resulting from agricultural duration are mostly found in temperate and boreal forests for the cropland simulations (here longer durations result in longer recovery times due to reduced $\mathrm{N}$ availability, Fig. 5) and in tropical forests and shrublands for the pasture simulations, emphasizing the importance of agricultural duration in these regions (see also Fig. 6b).

\subsection{Soil C recovery}

Relative depletion of soil $\mathrm{C}$ content under crop and pasture $\mathrm{LU}$ is not as large (loss of $0-11 \%$ compared to the reference simulation) as for vegetation C (Fig. 2). However, regeneration proceeds over longer timescales due to slower $\mathrm{C}$ accumulation in soils than in vegetation. $\mathrm{C}$ depletion is generally more pronounced for former crops than for pastures due to the greater harvest efficiency, which leads to more biomass removed each year, and the effect of tillage enhancing soil respiration (Sect. 2.1). Upon re-conversion, soil C accumulation is delayed for the pasture simulations compared to the cropland simulations, especially for P20, where the residual roots and other litter left after the original deforestation event continue to decay and soil $\mathrm{C}$ decreases for some decades. The general delay for pastures is associated with larger heterotrophic respiration rates (not shown) compared to rates calculated in recovering croplands.

Soil C recovery rates are highly latitude-dependent (Fig. 3), being much slower in temperate ( $\sim 250$ years) and boreal forests $(\sim 400$ years $)$ than in the tropics $(<100$ years, sometimes even within 5 years). Initial soil $\mathrm{C}$ depletions are larger in higher latitudes, while these regions also suffer from low productivity, thereby reducing $\mathrm{C}$ input to the soil upon regrowth. Additionally, in the intensive LU simulations (P100, C60, C100), vegetation productivity in the boreal region is further reduced compared to the reference simulation in the first 200 years of regrowth (not shown) due to $\mathrm{N} \mathrm{lim-}$ itation (Smith et al., 2014), reducing litter input to the soil even further.

Soil C recovery times differ substantially between simulations in many areas. LU type is particularly important in grasslands and non-tropical forests. While croplands tend to recover faster than pastures in grasslands of southern and northern Africa, the opposite occurs in most temperate and boreal forests but also the northern Sahel, where soil $\mathrm{C}$ after re-conversion from croplands does not recover at all. Post-agricultural $\mathrm{N}$ availability is enhanced in parts of the Sahel for the cropland simulations due to increased 

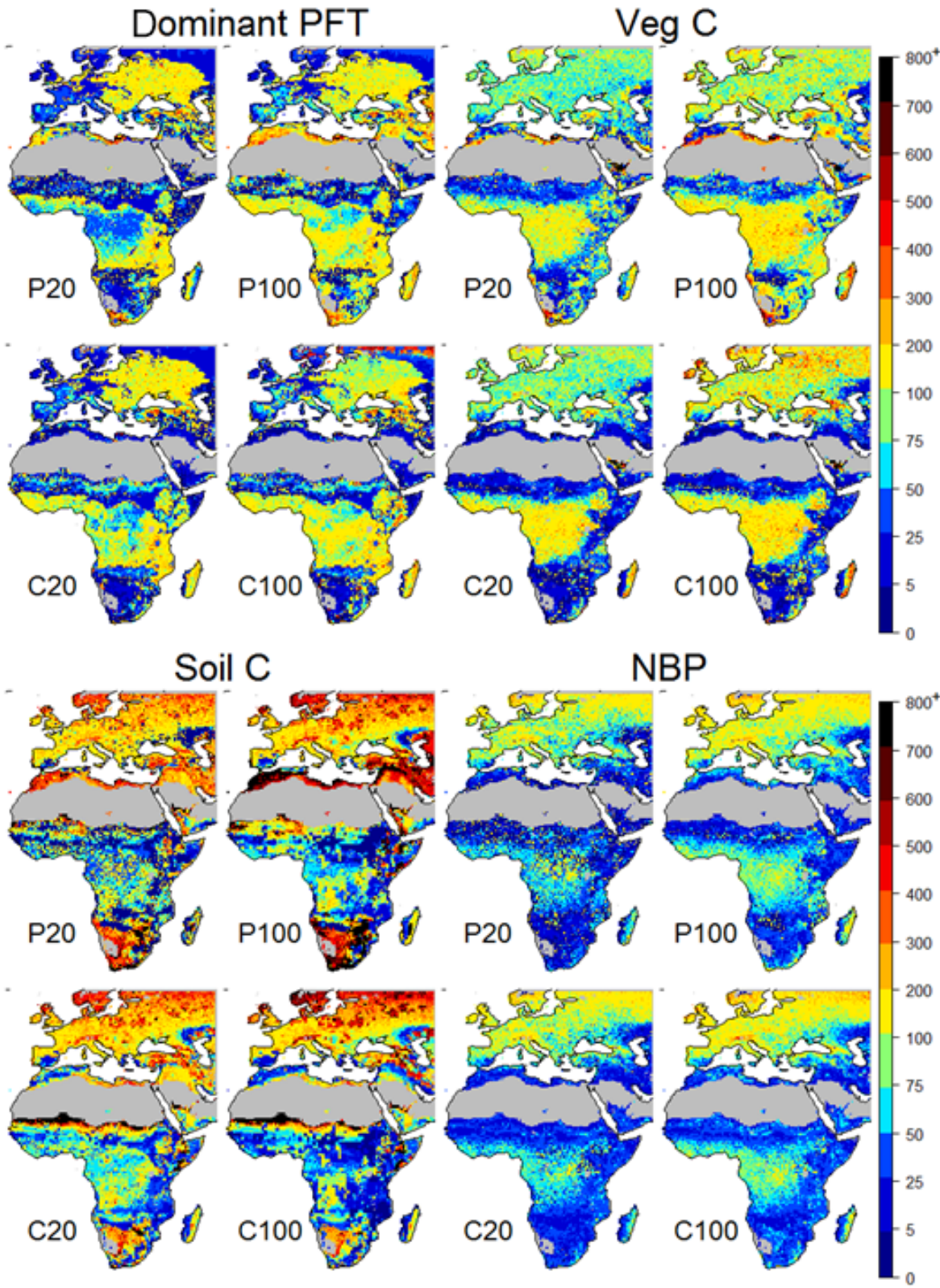

Figure 3. Maps of recovery times in years for the dominant PFT, vegetation C, soil C, and NBP for the P20, P100, C20, and C100 simulations.

$\mathrm{N}$ mineralization rates (Figs. 4 and 5), and trees benefit more than grasses, leading to a shift in the equilibrium vegetation state towards woody species (not shown), which results in an overall lower soil C pool size. It should be noted that even though some regions do not recover within 800 years, a large fraction of the original $\mathrm{C}$ loss is already replenished after a few centuries, thereby limiting implications for the $\mathrm{C}$ cycle. Counter to a priori expectations, for tropical and temperate forests and for shrublands, the difference between P20 and C20 is usually higher than between P60 and $\mathrm{C} 60$ or P100 and C100 (Fig. 6c). Pasture duration is relevant for speed of soil $\mathrm{C}$ recovery in most ecosystems and, apart from in the tropics, a longer duration usually delays recovery, mainly due to substantial initial depletions after long pasture durations (Fig. 2). For croplands, longer durations tend to delay recovery in temperate and boreal forests but accelerate soil $\mathrm{C}$ recovery in the (sub)tropics. This is somewhat unexpected for the tropical forest biome, where longer cropland durations usually do not increase $\mathrm{N}$ availability upon abandonment in our simulations (Fig. 5). However, while tropical soils lose large amounts of $\mathrm{C}$ during the first decades of cropland use, slow $\mathrm{C}$ accumulation takes place thereafter, resulting in higher soil $\mathrm{C}$ values at the end of the agricultural period for $\mathrm{C} 100$ than for $\mathrm{C} 20$ in large 


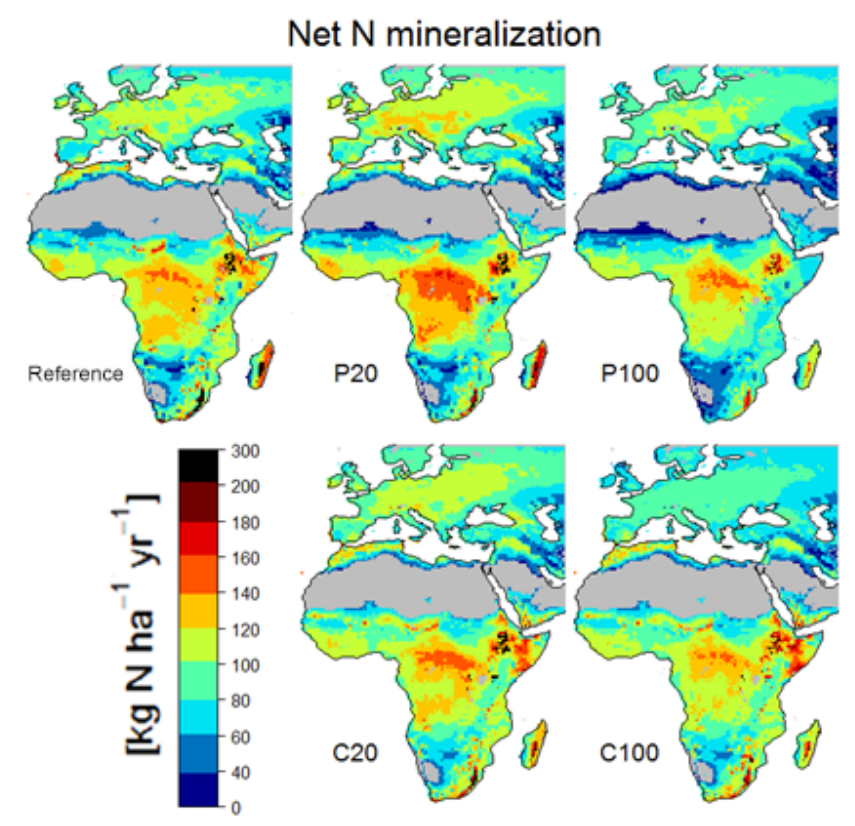

Figure 4. Average net $\mathrm{N}$ mineralization rates $\left(\mathrm{kg} \mathrm{Nha}^{-1} \mathrm{yr}^{-1}\right)$ in the soil for the reference simulation (full simulation period) and during the first 100 years of regrowth for the P20, P100, C20, and C100 simulations.

parts of eastern Africa. This occurs because tillage-driven $\mathrm{C}$ losses in more labile soil pools, which dominate the system's response during the first decades, are eventually supplanted as the dominant process by accumulation in more stable pools. This is different to temperate and boreal forest, where soil $\mathrm{C}$ decreases throughout the entire cropland period. Overall, the greatest sensitivity of soil $\mathrm{C}$ recovery times to different LU histories is found in boreal forests and grasslands, where maximum differences across simulations are often several centuries (Fig. 6c). The maximum differences across all simulations (P20/P60/P100/C20/C60/C100) in boreal forests are mainly due to differences across simulations of same LU type but different duration (e.g., P20/P60/P100), whereas the sensitivity of grasslands mainly reflects differences across simulations of different LU type but same duration (e.g., P100/C100), emphasizing the importance of duration and type of agriculture in a range of biomes.

\subsection{NBP recovery}

NBP switches from being a $\mathrm{C}$ source to the atmosphere during the period of land management to a $\mathrm{C}$ sink after reconversion to natural vegetation (Fig. 2). The sink capacity of the recovering ecosystem is greatest during the first decades and then gradually returns to the NBP levels of the reference simulation. P20 and, to a lesser extent, C20 act as a smaller sink than the other simulations at least during the first 100 years of regrowth. Recovery generally occurs slower in temperate and boreal regions than in the tropics for all sim-

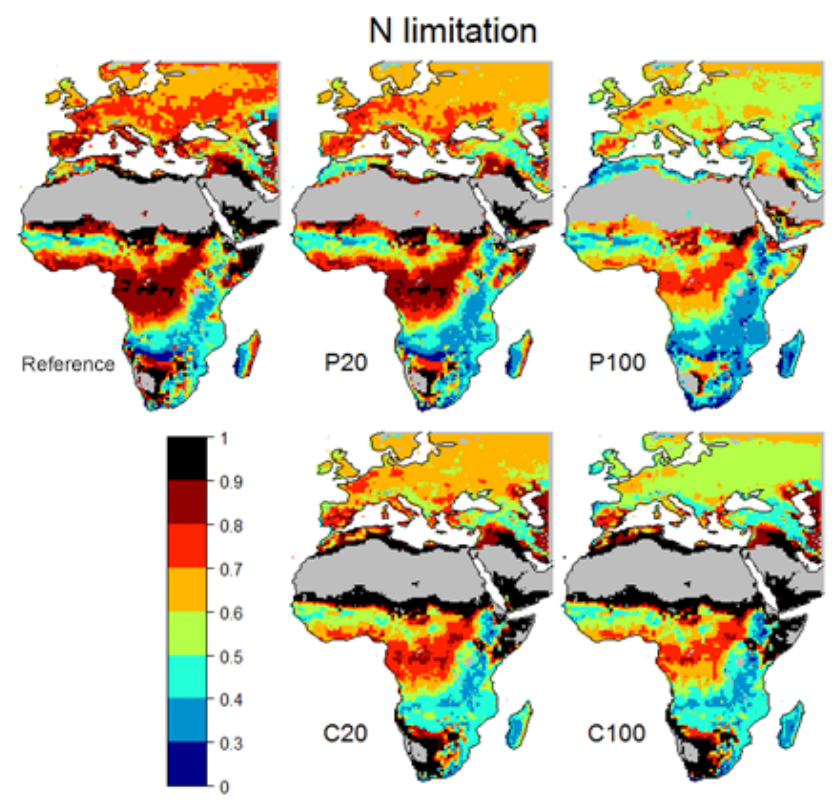

Figure 5. Average N limitation on vegetation RuBisCO capacity (and thus on gross primary production) for the reference simulation (full simulation period) and during the first 100 years of regrowth for the P20, P100, C20, and C100 simulations. N limitation is a number scaling from 0 (completely $\mathrm{N}$-limited) to 1 (no $\mathrm{N}$ limitation) (Smith et al., 2014).

ulations (Fig. 3). Apart from boreal forests, standard deviations of mean differences in recovery times are very small in all biomes compared to the other variables (Fig. 6d). Recovery times are often somewhat lower than those which would be expected from vegetation and soil $\mathrm{C}$ recovery times. This is because the greater standard deviation of NBP in our reference simulation (Fig. 2) reduces the threshold value in our recovery definition, thereby making it easier to reach recovery levels for NBP. We discuss the implications of this further in Sect. 4.2.

Differences in NBP recovery times between simulations are relatively small (typically a few years to decades; see Table 1). The largest differences in recovery times are found in the boreal forests between the cropland simulations, and, as for soil C, the differences are often greater between P20 and C20 than between P100 and C100 (Fig. 6d).

\section{Discussion}

\subsection{Comparison to observations and previous studies}

The effects of forest conversion to croplands or pastures are relatively well studied. Tilled croplands typically show large depletions of soil $\mathrm{C}$ compared to natural forest vegetation, but the picture for pasture is more diverse (Davidson and Ackerman, 1993; Don et al., 2011; Guo and Gifford, 2002). Table 2 summarizes recent reviews about observed soil $\mathrm{C}$ changes in agriculture compared to our results. LPJ-GUESS tends 

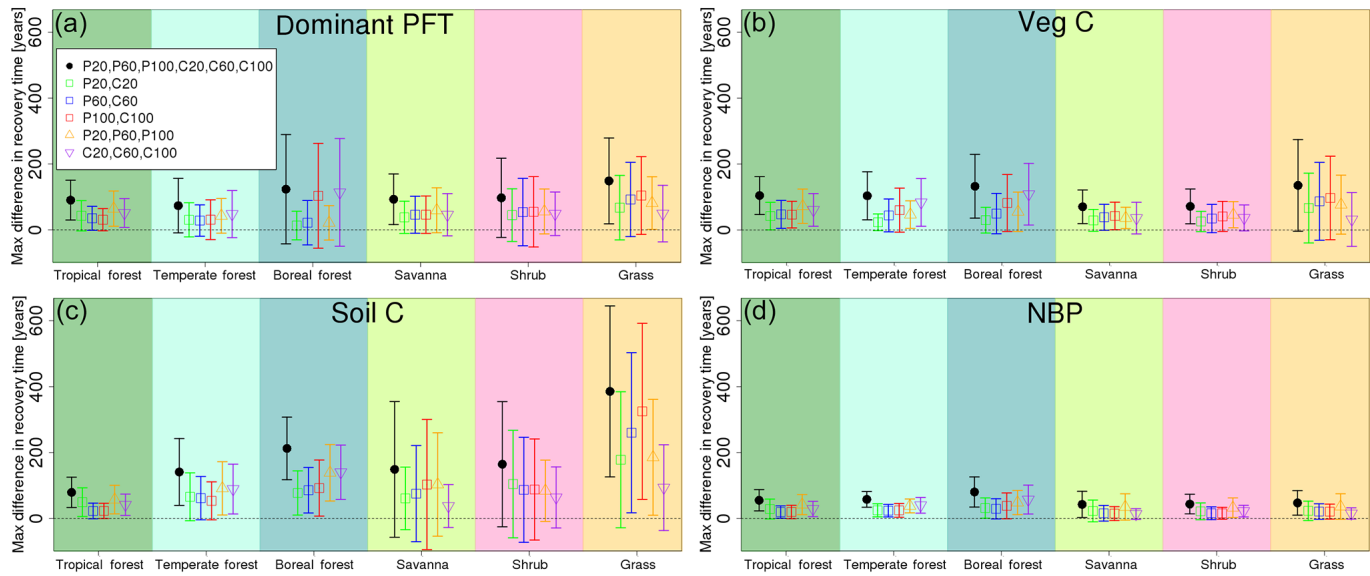

Figure 6. Maximum difference in recovery time (longest recovery time minus shortest recovery time of all selected simulations) for the dominant PFT, vegetation C, soil C, and NBP. Black dots show maximum differences across all six simulations (P20, P60, P100, C20, $\mathrm{C} 60, \mathrm{C} 100)$, green squares differences across 20-year pasture and cropland simulations (P20, C20), blue squares differences across 60-year pasture and cropland simulations (P60, C60), red squares differences across 100-year pasture and cropland simulations (P100, C100), orange triangles differences across pasture simulations (P20, P60, P100), and purple triangles differences across cropland simulations (C20, C60, $\mathrm{C} 100$ ). Background colors indicate associated biomes, arrows one standard deviation, and the dashed line 0 years' difference. Thus, the black dots show the sensitivity of recovery times to LU history across all simulations for each biome. The red, blue and green squares indicate the relative contribution of LU type for a specific LU duration to this sensitivity, and the orange and purple squares indicate the relative contributions of pasture and of cropland duration. For example, if recovery times for one variable in one grid cell were to be 50, 60, 65, 90, 100, 110 years (for P20, P60, P100, C20, C60, C100), the maximum difference in recovery time across all simulations (black) would be 60 years, across the 20-year simulations (green) 40 years, across the 60 -year simulations (blue) 40 years, across the 100 -year simulations (red) 45 years, across the pasture simulations (orange) 15 years and across the cropland simulations (purple) 20 years.

to simulate lower $\mathrm{C}$ loss in croplands than commonly reported in observations. We attribute this to a combination of the observation's focus on the top soil (while in LPJ-GUESS soil C is implicitly averaged over the whole soil column) and our relatively high fertilizer rates increasing productivity and thereby $\mathrm{C}$ input to the soil. Pugh et al. (2015) studied the $\mathrm{C}$ dynamics of soils in managed lands in LPJ-GUESS and found $\mathrm{C}$ accumulation even after 100 years of grazed pasture at some locations, especially for low atmospheric $\mathrm{CO}_{2}$ concentrations. However, they used the $\mathrm{C}$-only version of the model, thereby neglecting $\mathrm{C}-\mathrm{N}$ interactions and increased $\mathrm{N}$ limitation on grass growth with time due to $\mathrm{N}$ removal by harvest. Croplands were explicitly represented by a number of managed, but unfertilized, crop functional types in Pugh et al. (2015). They found soil $\mathrm{C}$ reductions in Europe and Africa of $\sim 50 \%$ after 100 years of cultivation, whereas in our study C losses were much smaller $(\sim 12 \%)$, possibly partly due to different tillage effects in the two soil models applied.

In contrast to studies of LU effects compared to previously natural ecosystems, the regeneration of ecosystems after agricultural abandonment has been studied less, and a direct comparison to our simulations is challenging, either because limited information about former LU or reference conditions was provided in these studies or because there are important differences from our setup in terms of management and LU duration or other site-specific characteristics. Additionally, most of the available studies were con- ducted in Amazonia or North America (Don et al., 2011) and there is large variability in physical and biotic characteristics as well as in land management (Kauffman et al., 2009). Many studies focus on the recovery of biodiversity or species richness (Cramer et al., 2008; Queiroz et al., 2014), but these variables cannot be adequately captured by our large-scale PFT approach. It is often assumed that the ecosystem will gradually return to its previous state and that intensive LU delays recovery but the timescales are widely unknown and differ across variables and regions, e.g., tropical species composition recovers much slower than forest structure and soil nutrients (Chazdon, 2003). Different recovery processes are strongly interlinked, e.g., vegetation accumulation and turnover are key factors in the replenishment of soil quality and nutrients which in turn determine plant productivity, and post-agricultural soil $\mathrm{C}$ and $\mathrm{N}$ dynamics have been shown to correlate during the regeneration of ecosystems (Knops and Tilman, 2000; Li et al., 2012).

Table 2 includes several studies about ecosystem vegetation and soil recovery after agricultural abandonment. Overall, the studies that looked at vegetation recovery upon abandonment indicate that biomass accumulation slows down after some decades and that accumulation rates correlate negatively with agricultural duration. Our simulations show that the rate of vegetation $\mathrm{C}$ sequestration indeed declines over time and that longer LU durations delay recovery in each of the analyzed biomes. Observations also indicate that use of 
Table 1. Average recovery times and standard deviations per biome and for each simulation. Recovery times are depicted in Fig. 3.

\begin{tabular}{|c|c|c|c|c|c|c|}
\hline \multirow[t]{2}{*}{ Biome } & \multicolumn{6}{|c|}{ Simulation } \\
\hline & $\mathrm{P} 20$ & P60 & P100 & $\mathrm{C} 20$ & C60 & $\mathrm{C} 100$ \\
\hline & \multicolumn{6}{|c|}{ Dominant PFT recovery time, averaged per biome } \\
\hline Tropical forest & $90 \pm 55$ & $112 \pm 48$ & $121 \pm 50$ & $113 \pm 54$ & $125 \pm 52$ & $126 \pm 51$ \\
\hline Temperate forest & $102 \pm 74$ & $96 \pm 63$ & $93 \pm 57$ & $99 \pm 71$ & $89 \pm 61$ & $92 \pm 69$ \\
\hline Boreal forest & $47 \pm 89$ & $52 \pm 97$ & $53 \pm 90$ & $47 \pm 95$ & $60 \pm 111$ & $145 \pm 178$ \\
\hline Savanna & $47 \pm 71$ & $57 \pm 74$ & $62 \pm 77$ & $50 \pm 65$ & $57 \pm 73$ & $59 \pm 76$ \\
\hline Shrub & $95 \pm 93$ & $104 \pm 101$ & $108 \pm 100$ & $103 \pm 100$ & $109 \pm 112$ & $109 \pm 112$ \\
\hline Grassland & $76 \pm 108$ & $102 \pm 109$ & $115 \pm 109$ & $45 \pm 77$ & $55 \pm 97$ & $58 \pm 100$ \\
\hline \multirow[t]{2}{*}{ Total } & $80 \pm 85$ & $93 \pm 84$ & $99 \pm 84$ & $77 \pm 78$ & $83 \pm 85$ & $90 \pm 95$ \\
\hline & \multicolumn{6}{|c|}{ Vegetation $\mathrm{C}$ recovery time, averaged per biome } \\
\hline Tropical forest & $106 \pm 50$ & $137 \pm 61$ & $150 \pm 65$ & $121 \pm 65$ & $138 \pm 73$ & $139 \pm 74$ \\
\hline Temperate forest & $84 \pm 24$ & $93 \pm 31$ & $108 \pm 46$ & $91 \pm 29$ & $124 \pm 59$ & $149 \pm 79$ \\
\hline Boreal forest & $102 \pm 47$ & $113 \pm 57$ & $127 \pm 71$ & $111 \pm 55$ & $144 \pm 79$ & $187 \pm 107$ \\
\hline Savanna & $49 \pm 37$ & $61 \pm 44$ & $66 \pm 46$ & $35 \pm 40$ & $42 \pm 43$ & $43 \pm 44$ \\
\hline Shrub & $73 \pm 40$ & $86 \pm 48$ & $96 \pm 51$ & $60 \pm 38$ & $69 \pm 48$ & $73 \pm 54$ \\
\hline Grassland & $96 \pm 136$ & $119 \pm 140$ & $126 \pm 138$ & $40 \pm 98$ & $43 \pm 102$ & $45 \pm 105$ \\
\hline \multirow[t]{2}{*}{ Total } & $88 \pm 80$ & $106 \pm 87$ & $117 \pm 90$ & $75 \pm 74$ & $92 \pm 87$ & $101 \pm 98$ \\
\hline & \multicolumn{6}{|c|}{ Soil $\mathrm{C}$ recovery time, averaged per biome } \\
\hline Tropical forest & $74 \pm 60$ & $69 \pm 43$ & $66 \pm 45$ & $80 \pm 46$ & $64 \pm 46$ & $49 \pm 43$ \\
\hline Temperate forest & $207 \pm 98$ & $229 \pm 105$ & $241 \pm 117$ & $237 \pm 108$ & $261 \pm 133$ & $260 \pm 144$ \\
\hline Boreal forest & $327 \pm 107$ & $381 \pm 122$ & $421 \pm 140$ & $362 \pm 112$ & $425 \pm 132$ & $454 \pm 161$ \\
\hline Savanna & $84 \pm 132$ & $132 \pm 191$ & $162 \pm 233$ & $85 \pm 112$ & $83 \pm 125$ & $74 \pm 126$ \\
\hline Shrub & $107 \pm 140$ & $129 \pm 161$ & $135 \pm 168$ & $137 \pm 173$ & $139 \pm 183$ & $125 \pm 183$ \\
\hline Grassland & $286 \pm 234$ & $366 \pm 262$ & $422 \pm 283$ & $239 \pm 227$ & $219 \pm 229$ & $198 \pm 228$ \\
\hline \multirow[t]{2}{*}{ Total } & $182 \pm 176$ & $220 \pm 209$ & $245 \pm 236$ & $182 \pm 171$ & $183 \pm 186$ & $174 \pm 194$ \\
\hline & \multicolumn{6}{|c|}{ NBP recovery time, averaged per biome } \\
\hline Tropical forest & $57 \pm 37$ & $65 \pm 26$ & $71 \pm 27$ & $56 \pm 28$ & $64 \pm 24$ & $65 \pm 24$ \\
\hline Temperate forest & $97 \pm 29$ & $108 \pm 29$ & $113 \pm 31$ & $102 \pm 30$ & $112 \pm 31$ & $119 \pm 36$ \\
\hline Boreal forest & $136 \pm 55$ & $146 \pm 56$ & $152 \pm 58$ & $139 \pm 54$ & $151 \pm 59$ & $169 \pm 71$ \\
\hline Savanna & $31 \pm 40$ & $34 \pm 30$ & $36 \pm 26$ & $29 \pm 18$ & $32 \pm 17$ & $33 \pm 17$ \\
\hline Shrub & $51 \pm 37$ & $58 \pm 31$ & $59 \pm 29$ & $52 \pm 27$ & $58 \pm 26$ & $59 \pm 25$ \\
\hline Grassland & $25 \pm 37$ & $31 \pm 31$ & $35 \pm 30$ & $27 \pm 15$ & $34 \pm 20$ & $36 \pm 22$ \\
\hline Total & $59 \pm 51$ & $66 \pm 49$ & $71 \pm 49$ & $60 \pm 45$ & $68 \pm 47$ & $72 \pm 52$ \\
\hline
\end{tabular}

land for pasture delays recovery in the tropics upon pasture abandonment compared to cropping, but in our simulations this seems to be the case only after long agricultural durations. For studies about soil $\mathrm{C}$ dynamics after agricultural abandonment, interpretation is often hindered by combining different soil layers or aggregating different LU types ( $\mathrm{Li}$ et al., 2012) and by large variations observed across studies (Post and Kwon, 2000). Nevertheless, most of the observed patterns are reproduced in our simulations, suggesting that LPJ-GUESS captures the salient processes: after abandonment, croplands accumulate $\mathrm{C}$ faster than pastures, and recovery often takes more than a century. The impact of LU duration has rarely been studied; however, our results suggest that even though longer agricultural durations mostly result in greater initial soil $\mathrm{C}$ depletions, recovery can occur at similar or even faster speed in the subtropics and tropics. In temperate and boreal forests long LU durations tend to delay recovery.

The LPJ-GUESS model has been successfully tested against a range of observations and observation-based products, including vegetation distribution and dynamics and soil $\mathrm{C}$ response to changes in vegetation cover (Hickler et al., 2004; Miller et al., 2008; Pugh et al., 2015; Smith et al., 2014). In our simulations, we used only two different agricultural land cover types (intensive grazing and fertilized, tilled crops). Our analysis would therefore not identify effects of, for instance, clearing technique (e.g., burning compared to mechanical removal) or different land management practices (e.g., repeated burning or irrigation) within one land cover type. For example, recovery of species richness and 
Table 2. Observations and LPJ-GUESS results of soil $\mathrm{C}$ changes during agriculture (cropland and/or pasture) and vegetation and soil $\mathrm{C}$ recovery after abandonment.

\begin{tabular}{|c|c|c|c|c|c|}
\hline $\begin{array}{l}\text { Observation } \\
\text { type }\end{array}$ & Biome & Observation value & $\begin{array}{l}\text { Closest } \\
\text { simulations } \\
\text { in terms of } \\
\text { LU history }\end{array}$ & $\begin{array}{l}\text { Average model value } \\
\text { for the specific biome }\end{array}$ & Reference \\
\hline
\end{tabular}

\begin{tabular}{|c|c|c|c|c|c|}
\hline \multicolumn{6}{|c|}{ Soil $\mathrm{C}$ changes during agriculture } \\
\hline $\begin{array}{l}\text { Soil C change } \\
\text { averaged over } \\
\text { different depths }\end{array}$ & global & $\begin{array}{l}42 \% \text { loss for forest- } \\
\text { cropland conversions, } \\
8 \% \text { gain for forest- } \\
\text { pasture conversions }\end{array}$ & $\begin{array}{l}\text { P20, P60, } \\
\text { P100, C20, } \\
\text { C60, C100 }\end{array}$ & $\begin{array}{l}7-17 \% \text { loss in forest } \\
\text { biomes for croplands, } \\
2 \% \text { gain to } 7 \% \text { loss } \\
\text { for pastures }\end{array}$ & $\begin{array}{l}\text { Guo and Gifford } \\
(2002)\end{array}$ \\
\hline $\begin{array}{l}\text { Soil C change at } \\
36 \mathrm{~cm}\end{array}$ & $\begin{array}{l}\text { tropical } \\
\text { forest }\end{array}$ & $\begin{array}{l}25 \% \text { loss for cropland, } \\
12 \% \text { loss for pasture/ } \\
\text { grassland }\end{array}$ & $\begin{array}{l}\text { C20, C60, } \\
\text { P20, P60 }\end{array}$ & $\begin{array}{l}11-12 \% \text { loss for } \\
\text { croplands, } 2 \% \text { gain to } \\
4 \% \text { loss for pastures }\end{array}$ & Don et al. (2011) \\
\hline $\begin{array}{l}\text { Soil C change at } \\
29 \mathrm{~cm}\end{array}$ & $\begin{array}{l}\text { temperate } \\
\text { forest }\end{array}$ & $\begin{array}{l}\text { new equilibrium after } \\
23 \text { years }\end{array}$ & $\mathrm{C} 100$ & $\begin{array}{l}\text { C loss throughout the } \\
\text { entire cropland } \\
\text { duration }\end{array}$ & Poeplau et al. (2011) \\
\hline \multicolumn{6}{|c|}{ Vegetation recovery after agricultural abandonment } \\
\hline $\begin{array}{l}\text { ag* vegetation } \\
\text { recovery time }\end{array}$ & $\begin{array}{l}\text { tropical } \\
\text { forest }\end{array}$ & 189 years & $\mathrm{C} 20$ & 121 years & $\begin{array}{l}\text { Saldarriaga et al. } \\
\text { (1988) }\end{array}$ \\
\hline $\begin{array}{l}\text { ag vegetation } \\
\text { recovery rate }\end{array}$ & $\begin{array}{l}\text { tropical } \\
\text { forest }\end{array}$ & $\begin{array}{l}\text { slowdown with time, } \\
\text { recovery slower for } \\
\text { pasture than for } \\
\text { cropland }\end{array}$ & $\begin{array}{l}\text { P20, P60, } \\
\text { P100, C20, } \\
\text { C60, C100 }\end{array}$ & $\begin{array}{l}\text { (slight) slowdown, } \\
\text { pasture recovery } \\
\text { slower only for long } \\
\text { durations (P100/C100) }\end{array}$ & Silver et al. (2000) \\
\hline $\begin{array}{l}\text { Total and } \\
\text { vegetation } \mathrm{C} \\
\text { recovery rate }\end{array}$ & $\begin{array}{l}\text { temperate } \\
\text { forest }\end{array}$ & linear with time & P60, P100 & (slight) slowdown & $\begin{array}{l}\text { Hooker and Compton } \\
(2003)\end{array}$ \\
\hline $\begin{array}{l}\text { Vegetation } \\
\text { recovery rate }\end{array}$ & $\begin{array}{l}\text { temperate } \\
\text { forest }\end{array}$ & linear with time & C20, C60 & (slight) slowdown & Poulton et al. (2003) \\
\hline $\begin{array}{l}\text { ag vegetation } \\
\text { recovery rate }\end{array}$ & $\begin{array}{l}\text { tropical } \\
\text { forest }\end{array}$ & $\begin{array}{l}\text { recovery speed } \\
\text { inversely related } \\
\text { to } L U \text { duration }\end{array}$ & $\begin{array}{l}\text { P20, P60, } \\
\text { P100 }\end{array}$ & $\begin{array}{l}\text { recovery speed } \\
\text { inversely related } \\
\text { to LU duration }\end{array}$ & Uhl et al. (1988) \\
\hline $\begin{array}{l}\text { ag vegetation } \\
\text { recovery rate } \\
\text { and time }\end{array}$ & $\begin{array}{l}\text { tropical } \\
\text { forest }\end{array}$ & $\begin{array}{l}73 \text { years, recovery } \\
\text { speed inversely related } \\
\text { to LU duration }\end{array}$ & $\begin{array}{l}\text { C20, C60, } \\
\text { C100 }\end{array}$ & $\begin{array}{l}121-139 \text { years, } \\
\text { recovery speed } \\
\text { inversely related } \\
\text { to } L U \text { duration }\end{array}$ & Hughes et al. (1999) \\
\hline $\begin{array}{l}\text { Maximum tree } \\
\text { height recovery } \\
\text { rate }\end{array}$ & $\begin{array}{l}\text { tropical } \\
\text { forest }\end{array}$ & $\begin{array}{l}\text { recovery speed } \\
\text { inversely related } \\
\text { to LU duration }\end{array}$ & $\begin{array}{l}\text { C20, C60, } \\
\text { C100 }\end{array}$ & $\begin{array}{l}\text { recovery speed } \\
\text { inversely related } \\
\text { to LU duration }\end{array}$ & $\begin{array}{l}\text { Randriamalala et al. } \\
\text { (2012) }\end{array}$ \\
\hline $\begin{array}{l}\text { Vegetation } \\
\text { height recovery } \\
\text { rate }\end{array}$ & $\begin{array}{l}\text { tropical } \\
\text { forest }\end{array}$ & $\begin{array}{l}\text { slower for pasture } \\
\text { than for cropland }\end{array}$ & $\begin{array}{l}\text { P20, P60, } \\
\text { P100, C20, } \\
\text { C60, C100 }\end{array}$ & $\begin{array}{l}\text { slower only for long } \\
\text { durations (C100/P100) }\end{array}$ & Moran et al. (2000) \\
\hline $\begin{array}{l}\text { ag vegetation } \\
\text { recovery rate }\end{array}$ & $\begin{array}{l}\text { tropical } \\
\text { forest }\end{array}$ & $\begin{array}{l}\text { slower for pasture } \\
\text { than for cropland }\end{array}$ & $\mathrm{P} 20, \mathrm{C} 20$ & $\begin{array}{l}\text { faster for P20 than for } \\
\text { C20 }\end{array}$ & $\begin{array}{l}\text { Wandelli and } \\
\text { Fearnside (2015) }\end{array}$ \\
\hline \multicolumn{6}{|c|}{ Soil C recovery after agricultural abandonment } \\
\hline $\begin{array}{l}\text { Soil C recovery } \\
\text { at up to } 30 \mathrm{~cm}\end{array}$ & global & $\begin{array}{l}\text { large variation across } \\
\text { studies, tendency to } \\
\text { lose } \mathrm{C} \text { in the first years } \\
\text { for pastures, immediate } \\
\text { accumulation for } \\
\text { croplands }\end{array}$ & $\begin{array}{l}\text { P20, P60, } \\
\text { P100, C20, } \\
\text { C60, C100 }\end{array}$ & $\begin{array}{l}\text { tendency to lose } \mathrm{C} \text { in } \\
\text { the first years for } \\
\text { pastures, immediate } \\
\text { accumulation for } \\
\text { croplands }\end{array}$ & Paul et al. (2002) \\
\hline
\end{tabular}

* ag = aboveground. 
Table 3. Observations and LPJ-GUESS results of soil C changes during agriculture (cropland and/or pasture) and vegetation and soil C recovery after abandonment.

\begin{tabular}{|c|c|c|c|c|c|}
\hline $\begin{array}{l}\text { Observation } \\
\text { type }\end{array}$ & Biome & Observation value & $\begin{array}{l}\text { Closest } \\
\text { simulations } \\
\text { in terms of } \\
\text { LU history }\end{array}$ & $\begin{array}{l}\text { Average model value } \\
\text { for the specific biome }\end{array}$ & Reference \\
\hline $\begin{array}{l}\text { Soil C recovery } \\
\text { at } 34 \mathrm{~cm}\end{array}$ & global & $\begin{array}{l}\text { more accumulation for } \\
\text { croplands than for } \\
\text { pastures, no } \\
\text { accumulation in boreal } \\
\text { zone }\end{array}$ & $\begin{array}{l}\text { P20, P60, } \\
\text { P100, C20, } \\
\text { C60, C100 }\end{array}$ & $\begin{array}{l}\text { more accumulation for } \\
\text { croplands than for } \\
\text { pastures, slower } \\
\text { accumulation in boreal } \\
\text { zone }\end{array}$ & $\begin{array}{l}\text { Laganiere et al. } \\
(2010)\end{array}$ \\
\hline $\begin{array}{l}\text { Soil C recovery } \\
\text { at } 28 / 40 \mathrm{~cm}\end{array}$ & $\begin{array}{l}\text { temperate } \\
\text { forest }\end{array}$ & $\begin{array}{l}\text { linear accumulation, no } \\
\text { equilibrium after } \\
120 \text { years }\end{array}$ & $\mathrm{C} 20$ & $\begin{array}{l}\text { linear accumulation, no } \\
\text { equilibrium after } \\
120 \text { years }\end{array}$ & Poeplau et al. (2011) \\
\hline $\begin{array}{l}\text { Soil C recovery } \\
\text { time at } 0-60 \mathrm{~cm}\end{array}$ & grassland & 158 years & $\mathrm{C} 100$ & 198 years & Potter et al. (1999) \\
\hline $\begin{array}{l}\text { Soil C recovery } \\
\text { time at } 0-60 \mathrm{~cm}\end{array}$ & $\begin{array}{l}\text { savanna/ } \\
\text { temperate } \\
\text { forest }\end{array}$ & 230 years & $\mathrm{C} 20$ & $\begin{array}{l}85 \text { (savanna)/237 } \\
\text { (temperate forest) years }\end{array}$ & $\begin{array}{l}\text { Knops and Tilman } \\
(2000)\end{array}$ \\
\hline $\begin{array}{l}\text { Soil C recovery } \\
\text { time } 0-10 \mathrm{~cm}\end{array}$ & $\begin{array}{l}\text { temperate } \\
\text { forest }\end{array}$ & $>100$ years & $\begin{array}{l}\text { C20, C60, } \\
\text { C100 }\end{array}$ & 237-261 years & $\begin{array}{l}\text { Foote and Grogan } \\
\text { (2010) }\end{array}$ \\
\hline $\begin{array}{l}\text { Soil C recovery } \\
\text { time } 0-25 \mathrm{~cm}\end{array}$ & $\begin{array}{l}\text { tropical } \\
\text { forest }\end{array}$ & $50-60$ years & $\begin{array}{l}\text { P20, P60, } \\
\text { P100, C20, } \\
\text { C60, C100 }\end{array}$ & 49-80 years & Silver et al. (2000) \\
\hline
\end{tabular}

maximum tree height of secondary forests occurs faster under no tillage compared to heavy tillage (Randriamalala et al., 2012).

Our study is intended as an idealized experiment to highlight the importance of LU history on ecosystem state and fluxes across biomes. Still, some processes with the potential to affect post-agricultural ecosystem recovery, at least regionally, are not currently included in LPJ-GUESS. One aspect is the phosphorus cycle, which is not implemented in LPJ-GUESS, even though it can be significantly altered by LUC (MacDonald et al., 2012; McLauchlan, 2006). Moreover, while $\mathrm{C}$ and $\mathrm{N}$ cycles interact in LPJ-GUESS (Smith et al., 2014), the uniform annual fertilizer rate we applied in this study might be realistic in some regions, such as parts of Europe, but exceeds present-day fertilizer use in Africa (Potter et al., 2010). Seed availability, remnant trees and resprouting from surviving roots are important factors during initial stages of tree colonization following agricultural cessation (Bellemare et al., 2002; Cramer et al., 2008). While LPJGUESS does not account for these effects explicitly, seedling establishment is limited by a suitable growth environment, such that effects like re-sprouting or remnant trees as seed sources are mimicked. The model has been shown to, for example, reproduce vegetation recolonization in northern Europe during the Holocene well (Miller et al., 2008), as well as canopy structural changes as a function of forest age (Smith et al., 2014). What is more, by using a prescribed climate in our simulations, hydrological biosphere-atmosphere interactions and feedbacks are not captured (Eltahir and Bras, 1996; Giambelluca, 2002), which could alter regional climate in response to land cover change, potentially affecting recovery rates, especially in tropical regions. Biophysical effects are not restricted to modifications of the water cycle but also include changes in surface albedo and roughness length as a function of ecosystem structure and composition, thereby affecting air mixing and heat transfer. While forests generally absorb more sunlight than grasslands (e.g., Culf et al., 1995), differences amongst tree species and age classes exist as well. Substantial impacts related to realistic land-use have been found on local-to-regional scales (Alkama and Cescatti, 2016; Peng et al., 2014). Whether or not the locally observed changes translate to a significant global radiative forcing is still debated as the direction of change differs across regions in some climate models, which may cancel when integrated globally (Pielke et al., 2011). Additionally, while we focus on $\mathrm{C}$ sequestration rates in our analysis, there might be biogeochemical implications beyond $\mathrm{C}$. For instance, the emissions of biogenic volatile organic compounds (BVOCs) to the atmosphere vary greatly amongst plant species (Kesselmeier and Staudt, 1999). BVOCs affect atmospheric composition and climate via ozone production, lengthening the lifetime of atmospheric methane, and contributing to secondary organic aerosol formation (Penuelas and Staudt, 2010; Wu et al., 2012). BVOC emission factors might also be drastically 
influenced by wildfires (Ciccioli et al., 2014), which in turn are driven by species composition and vegetation density. Thus, different successional trajectories of ecosystem structure and composition recovery have the potential to directly modify air quality and climatic conditions under which regrowth occurs, potentially creating positive or negative climate system feedbacks.

\subsection{Implications of recovery definition}

The term recovery is subjective and, in the absence of a universal definition amongst ecologists, several definitions currently exist. The definition used in this study examines recovery from a $\mathrm{C}$ sequestration perspective which does not capture situations, for example, where the system approaches a new equilibrium (as soil $\mathrm{C}$ did in some regions in the cropland simulations). In order to obtain a better understanding of the uncertainties related to our definition we therefore explored four alternative plausible recovery definitions.

When applying a mean minus $2 \sigma$ threshold (instead of a mean minus $1 \sigma$ threshold), recovery times are generally shorter, e.g., on average 75 instead of 106 years for vegetation $\mathrm{C}$ in $\mathrm{P} 60$, but the overall geographic patterns are very consistent across both definitions (not shown). For all variables and simulations, notable differences between both definitions occur in regions with longest recovery times, especially for subtropical soil $\mathrm{C}$ in the pasture simulations.

Recovery based on percentage change (Fig. A4) results in more heterogeneous patterns across variables when compared to our standard recovery definition. Applying a threshold of $95 \%$ of the mean, instead of a mean minus $1 \sigma$ threshold, produces slightly longer dominant PFT recovery times in parts of the temperate and tropical forests, and shorter recovery times in grasslands, especially for the pasture simulations. Vegetation $\mathrm{C}$ shows similar patterns to the dominant PFT; however, the differences to our standard definition are more pronounced. Soil C recovery times generally decrease dramatically, especially outside the tropics. NBP recovery times generally increase, particularly in forest ecosystems.

By expanding our standard recovery definition by an upper threshold (reference mean plus $1 \sigma$ ), and with the "minimum rule" also applied to the maximum (see Sect. 2.4), one can test whether some ecosystems recover from higher rather than lower values than in the reference simulation. Mostly grasslands are affected by this alternative definition (Fig. A5). Dominant PFT recovery under this definition takes slightly longer throughout the African grasslands for the pasture simulations, and considerably longer in parts of northern and southern Africa for the cropland simulations. Patterns are similar for vegetation $\mathrm{C}$, but the increase in vegetation $\mathrm{C}$ recovery times is often larger than the increase in dominant PFT recovery times, especially for croplands. Soil C recovery is notably longer in subtropical and eastern African grasslands. The recovery times of NBP are hardly affected. However, we do not use an upper threshold in the primary defi- nition used in this study because in this case the ecosystem is already operating at a level of service above that which the undisturbed ecosystem would have provided and our aim here was to investigate recovery from a depletion perspective.

Finally, when using the mean $\pm 1 \sigma$ definition and additionally checking whether the variable is still in the mean $\pm 1 \sigma$ range at the end of the simulation period (not shown), many grid cells did not recover even within the set maximum cut-off of 800 years. Elements of random fluctuations due to natural variability arising from stochastic processes and disturbances and responding $\mathrm{C}, \mathrm{N}$, and water dynamics made a clear identification of recovery period difficult in that case. In particular for soil $\mathrm{C}$, no recovery is found for parts of eastern and subtropical Africa. The system converges towards a new equilibrium state in these regions which lies above reference values. NBP stays within background levels everywhere.

Altogether, the alternative recovery definitions agree on the general findings when applying our standard definition, especially in terms of relative recovery rates. For all definitions, vegetation $\mathrm{C}$ and dominant PFT recover faster in grasslands than in forest-dominated ecosystems, and soil $\mathrm{C}$ recovery takes much longer in higher latitudes. However, some areas, especially in the subtropics, "recover" from values higher than in the reference simulation, and these cases are not captured by our standard definition. Additionally, in the tropics, soil $\mathrm{C}$ accumulation sometimes does not stop once background values are reached and soil $\mathrm{C}$ leaves the reference range. When recovery is defined based on standard deviation, NBP recovery is often quicker than recovery of the $\mathrm{C}$ pools. This inconsistency emphasizes the importance of both recovery definition and selected variables when studying the recovery of ecosystems (Jones and Schmitz, 2009). This is particularly relevant for flux tower measurements, where an underlying long-term trend caused by the recovery from previous, often unquantified or unknown LU change, might be overlooked due to a large interannual variability in net ecosystem exchange.

\section{Conclusions}

Most studies which have explored the effects of distant human activities on present-day ecosystems were restricted by sampling difficulties, small spatial scales, short time periods since abandonment, and little information about background conditions or the specific LU history of the site. Here, we use a model-based approach to study the legacy effects of agricultural LU history (type and duration) on ecosystem regeneration and $\mathrm{C}$ sink capacity after the cessation of agriculture in a range of biomes across Europe and Africa. The model reproduces qualitatively the response found at study locations, including distinct differences in recovery between different variables of the terrestrial carbon cycle. Long-lasting legacy 
effects of former agricultural intensity emerge as important for present-day ecosystem functions. These findings have implications for various scientific applications:

1. Long-term monitoring sites (e.g., FLUXNET) and Earth observation systems need to collect and maintain detailed information about past and present land cover and land management to adequately interpret their data.

2. Assessments of trends in data from sites that seek to identify impacts of climate change and/or increasing atmospheric $\mathrm{CO}_{2}$ concentration need to make sure that legacy effects of past LU are not confounding the observed trends.

3. Simulation experiments need to move beyond deforestation but also represent, in a more detailed manner, re-growth dynamics following agricultural abandonment at the sub-grid level. At the moment a few DGVMs have started to do so (Shevliakova et al., 2009; Stocker et al., 2014; Wilkenskjeld et al., 2014) based on model products of tropical shifting cultivation (Hurtt et al., 2011), but accounting for gross land cover changes is also important in other regions like Europe (Fuchs et al., 2015). Failure to consider LU history may lead to errors in the simulation of vegetation properties, potentially resulting in biases in carbon sequestration or energy balance calculations, with subsequent implications for simulations of regional and global climate. Our study suggests that, for vegetation and soil $\mathrm{C}$ studies, accounting for LUC over the last $100-150$ years is sufficient in the tropics, while more than 200 years might be necessary in the temperate and boreal zone; studies restricted to vegetation should not have to account for LUC more than 150 years ago in any major climatic zone.
4. Assessing the efficiency of climate mitigation through large-scale reforestation or afforestation projects will require knowledge about the type and duration of previous LU. Our simulations suggest that the potential to rapidly sequester $\mathrm{C}$ in biomass and soil is greatest in tropical forests following short periods of cropland, while boreal forests accumulate $\mathrm{C}$ slowest, especially when previously used for pasture. Special attention should be paid to monitoring changes in belowground $\mathrm{C}$, as in most places the accumulation of soil $\mathrm{C}$ is much more sensitive to LU history than $\mathrm{C}$ accumulation in re-growing trees.

5. In terms of soil $\mathrm{C}$, our results suggest that some subtropical regions might not recover at all on timescales relevant for humans. However, given the low absolute amounts of C "missing" in these soils, implications for the global $\mathrm{C}$ cycle are expected to be small.

\section{Data availability}

Researchers interested in the LPJ-GUESS source code can contact the model developers (http://iis4.nateko.lu.se/ lpj-guess/contact.html). The CRU TS 3.21 climate data can be downloaded from http://browse.ceda.ac.uk/browse/ badc/cru/data/cru_ts/cru_ts_3.21. The LPJ-GUESS simulation data are stored at the IMK-IFU computing facilities and can be obtained on request (andreas.krause@kit.edu). 


\section{Appendix A: Additional tables and figures}

Table A1. Plant functional types used in this study.

\begin{tabular}{ll}
\hline BNE & Boreal needleleaved evergreen tree \\
BINE & Boreal shade-intolerant needleleaved evergreen tree \\
BNS & Boreal needleleaved summergreen tree \\
TeBS & Shade-tolerant temperate broadleaved summergreen tree \\
IBS & Shade-intolerant broadleaved summergreen tree \\
TeBE & Temperate broadleaved evergreen tree \\
TrBE & Tropical broadleaved evergreen tree \\
TrIBE & Tropical shade-intolerant broadleaved evergreen tree \\
TrBR & Tropical broadleaved raingreen tree \\
C3G & Cool $\mathrm{C}_{3}$ grass \\
C4G & Warm $\mathrm{C}_{4}$ grass \\
\hline
\end{tabular}

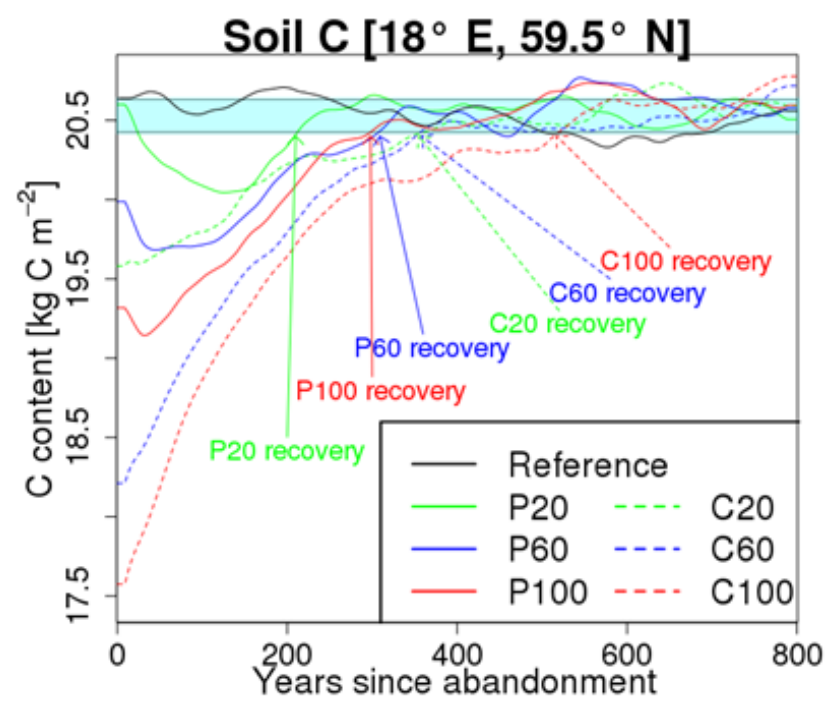

Figure A1. Soil C for the six simulations after conversion to natural vegetation at one single example site to illustrate how recovery time was calculated according to our definition. The cyan-shaded area corresponds to reference simulation mean $\pm 1 \sigma$. When soil $\mathrm{C}$ exceeds the mean $-1 \sigma$ threshold and the time of the minimum (which in this case is located in the first 200 years and below the mean $-1 \sigma$ threshold for all six simulations) is passed, recovery is achieved. 

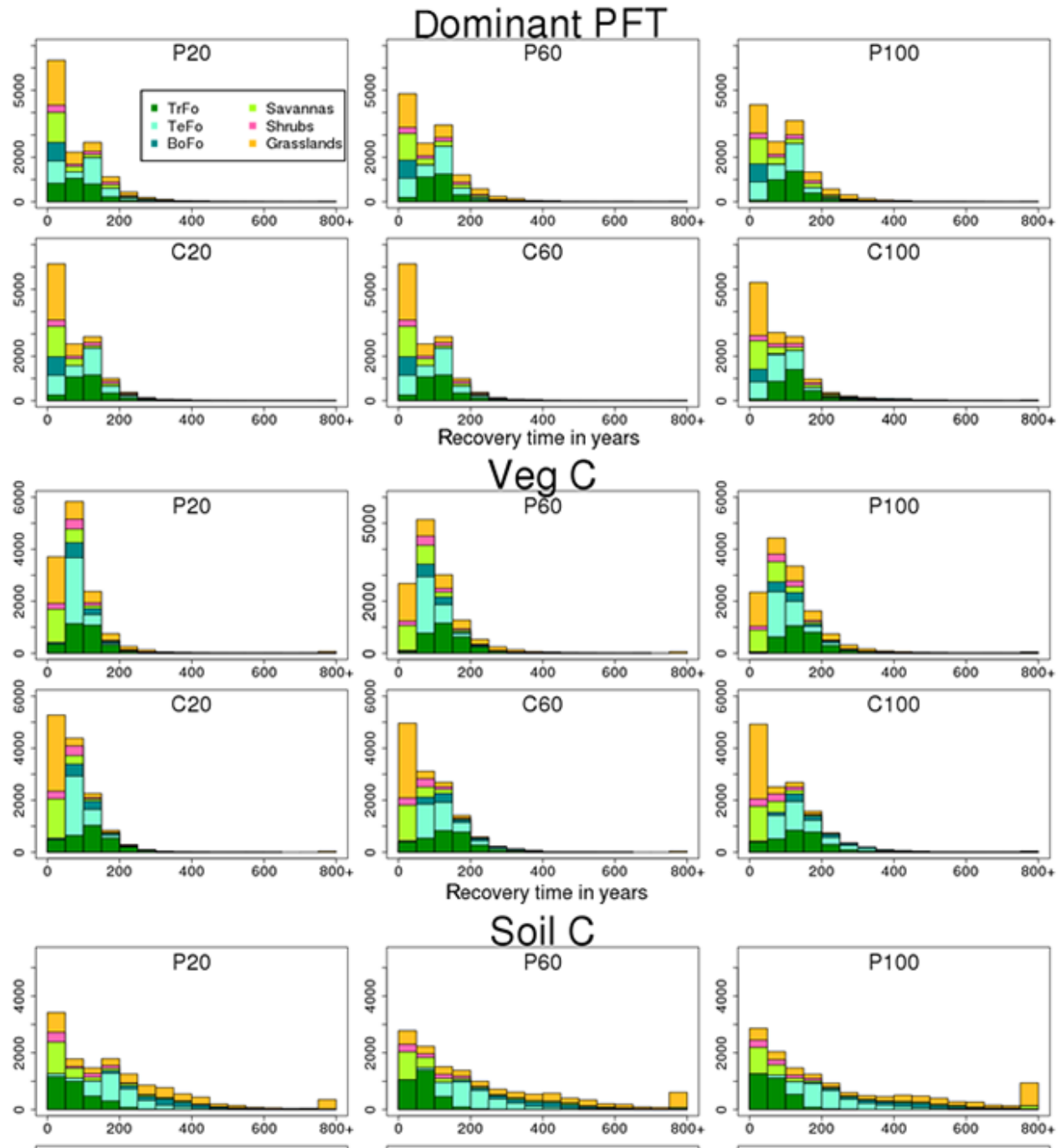

Soil C
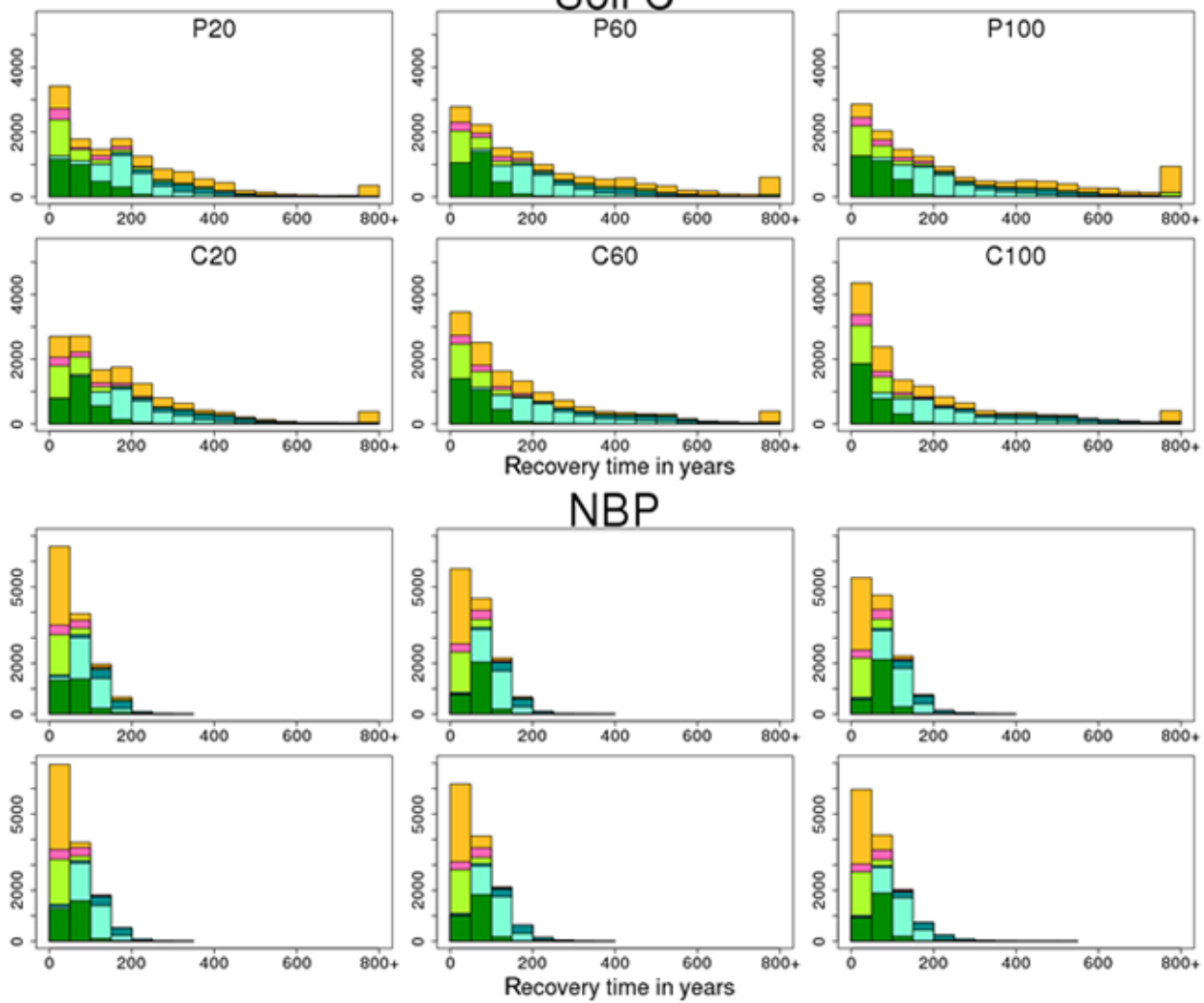

Figure A2. Histograms of recovery times for the dominant PFT, vegetation C, soil C, and NBP for the six experiments. Colors indicate different biomes. 


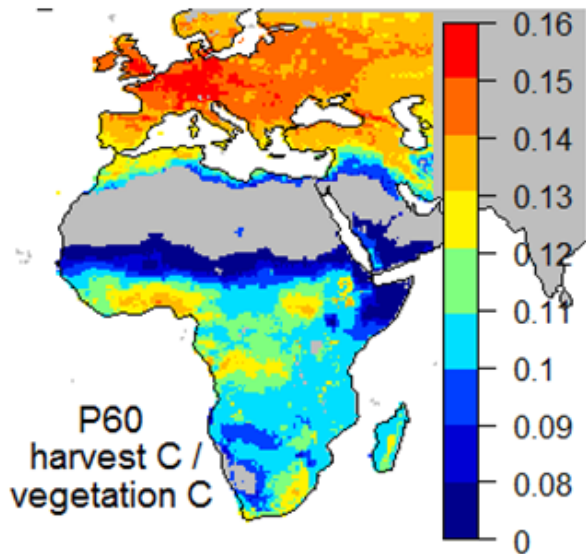

Figure A3. Annual ratio of $\mathrm{C}$ removed by harvest and $\mathrm{C}$ stored in vegetation, averaged over the whole agricultural period and for P60. As only aboveground biomass is harvested, lower values indicate increased $\mathrm{C}$ allocation to roots compared to leaves due to limited water supply.

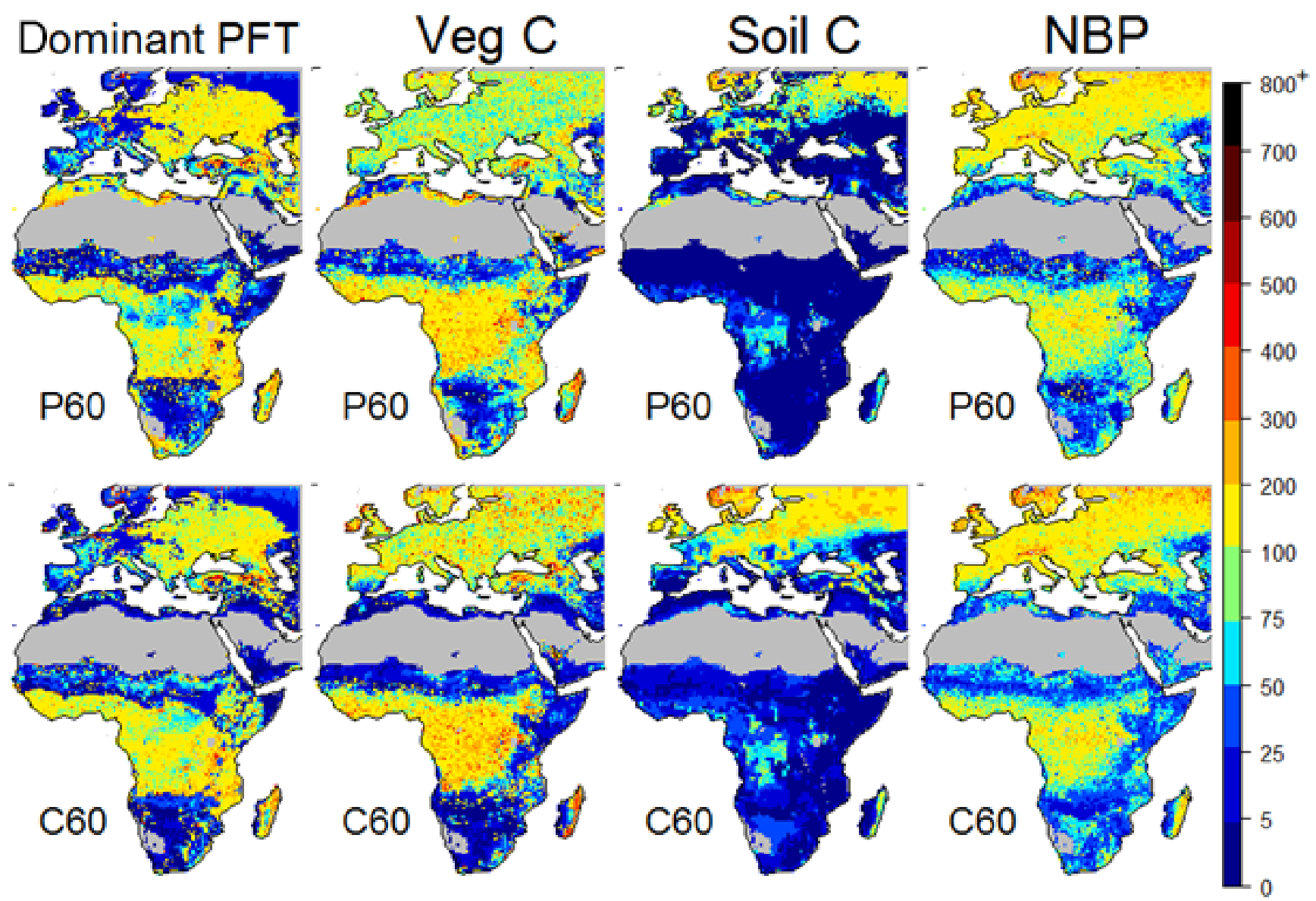

Figure A4. Maps of recovery time for the dominant PFT, vegetation C, soil C and NBP with an alternative recovery definition for the P60 and C60 simulations. The definition is the same as our standard definition but with a mean $\cdot 0.95$ threshold instead of mean $-1 \sigma$. 


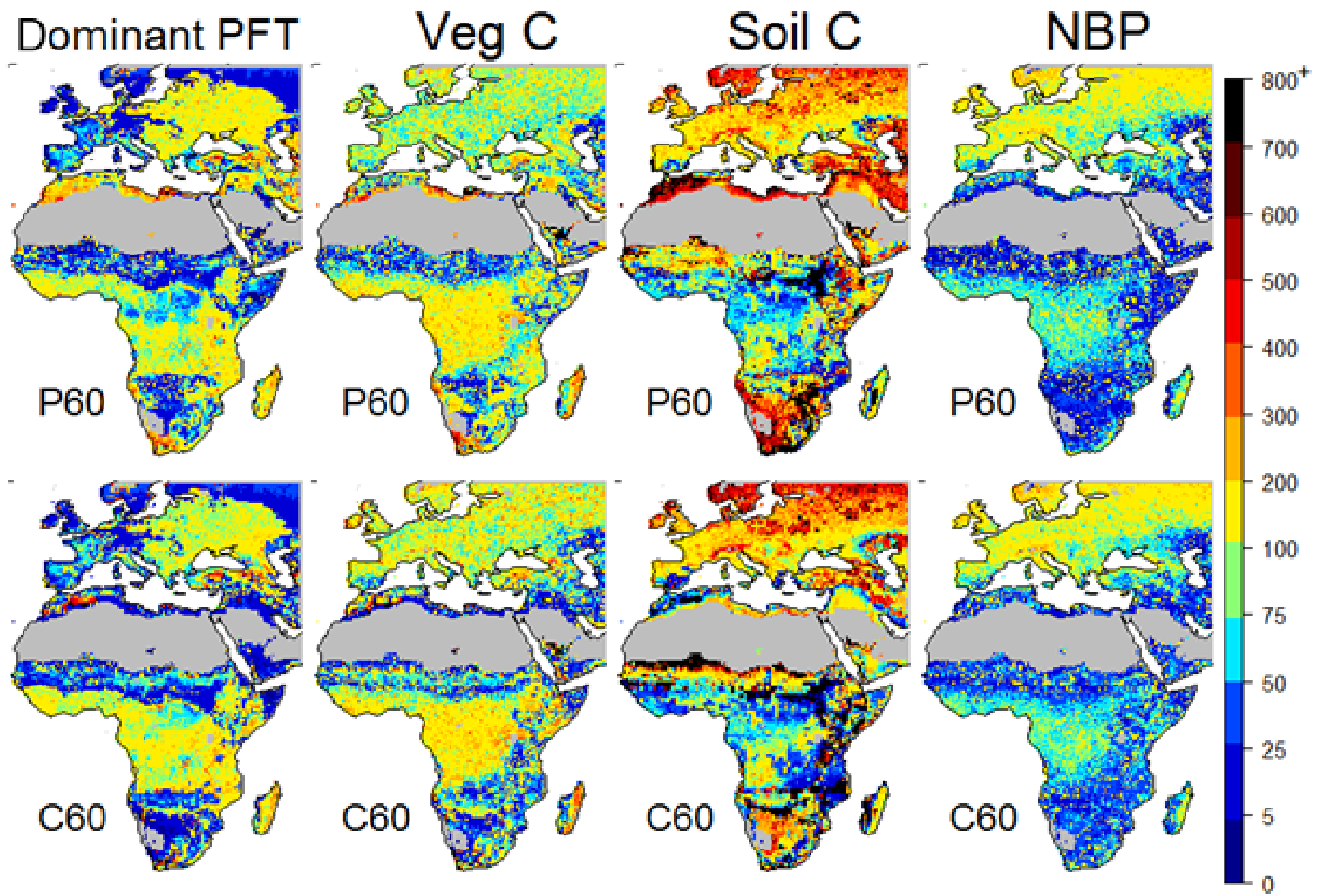

Figure A5. Maps of recovery time for the dominant PFT, vegetation C, soil C and NBP with an alternative recovery definition for the P60 and C60 simulations. The definition is the same as our standard definition but with a mean $\pm 1 \sigma$ threshold and the minimum check also applied to the maximum instead of a mean $-1 \sigma$ threshold and only checking the minimum. 
Acknowledgements. This work was funded by the Helmholtz Association through the International Research Group CLUCIE and by the European Commission's 7th Framework Programme, under grant agreement number 603542 (LUC4C). A. D. Bayer acknowledges support by the European Commission's 7th Framework Programme, under grant agreement number 308393 (OPERAs). This work was supported, in part, by the German Federal Ministry of Education and Research (BMBF), through the Helmholtz Association and its research program ATMO. It also represents paper number 20 of the Birmingham Institute of Forest Research.

The article processing charges for this open-access publication were covered by a Research

Centre of the Helmholtz Association.

Edited by: V. Arora

two anonymous referees

\section{References}

Aide, T. M., Zimmerman, J. K., Pascarella, J. B., Rivera, L., and Marcano-Vega, H.: Forest regeneration in a chronosequence of tropical abandoned pastures: Implications for restoration ecology, Restor. Ecol., 8, 328-338, doi:10.1046/j.1526100x.2000.80048.x, 2000.

Alkama, R. and Cescatti, A.: Biophysical climate impacts of recent changes in global forest cover, Science, 351, 600-604, doi:10.1126/science.aac8083, 2016.

Arora, V. K. and Montenegro, A.: Small temperature benefits provided by realistic afforestation efforts, Nat. Geosci., 4, 514-518, doi:10.1038/NGEO1182, 2011.

Bayer, A. D., Pugh, T. A. M., Krause, A., and Arneth, A.: Historical and future quantification of terrestrial carbon sequestration from a greenhouse-gas-value perspective, Global Environ. Change, 32, 153-164, doi:10.1016/j.gloenvcha.2015.03.004, 2015.

Bellemare, J., Motzkin, G., and Foster, D. R.: Legacies of the agricultural past in the forested present: An assessment of historical land-use effects on rich mesic forests, J. Biogeogr., 29, 14011420, doi:10.1046/j.1365-2699.2002.00762.x, 2002.

Brovkin, V., Boysen, L., Arora, V. K., Boisier, J. P., Cadule, P., Chini, L., Claussen, M., Friedlingstein, P., Gayler, V., van den Hurk, B. J. J. M., Hurtt, G. C., Jones, C. D., Kato, E., de NobletDucoudre, N., Pacifico, F., Pongratz, J., and Weiss, M.: Effect of anthropogenic land-use and land-cover changes on climate and land carbon storage in CMIP5 projections for the twentyfirst century, J. Climate, 26, 6859-6881, doi:10.1175/Jcli-D-1200623.1, 2013.

Burgi, M. and Turner, M. G.: Factors and processes shaping land cover and land cover changes along the Wisconsin River, Ecosystems, 5, 184-201, doi:10.1007/s10021-001-0064-6, 2002.

Campbell, J. E., Lobell, D. B., Genova, R. C., and Field, C. B.: The global potential of bioenergy on abandoned agriculture lands, Environ. Sci. Technol., 42, 5791-5794, doi:10.1021/es800052w, 2008.

Chazdon, R. L.: Tropical forest recovery: Legacies of human impact and natural disturbances, Perspect. Plant Ecol., 6, 51-71, doi:10.1078/1433-8319-00042, 2003.
Chazdon, R. L.: Second growth: The promise of tropical forest regeneration in an age of deforestation, University of Chicago Press, Chicago, Illinois, USA, 2014.

Ciccioli, P., Centritto, M., and Loreto, F.: Biogenic volatile organic compound emissions from vegetation fires, Plant Cell Environ., 37, 1810-1825, doi:10.1111/pce.12336, 2014.

Compton, J. E. and Boone, R. D.: Long-term impacts of agriculture on soil carbon and nitrogen in New England forests, Ecology, 81, 2314-2330, 2000.

Cramer, V. A., Hobbs, R. J., and Standish, R. J.: What's new about old fileds? Land abandonment and ecosystem assembly, Trends Ecol. Evol., 23, 104-112, doi:10.1016/j.tree.2007.10.005, 2008.

CRU: CRU TS3.21: Climatic Research Unit (CRU) time-series (TS) version 3.21 of high resolution gridded data of month-by-month variation in climate (Jan. 1901-Dec. 2012), NCAS British Atmospheric Data Centre, doi:10.5285/D0E1585D-3417-485F-87AE4FCECF10A992, 2013.

Culf, A. D., Fisch, G., and Hodnett, M. G.: The albedo of Amazonian forest and ranch land, J. Climate, 8, 1544-1554, doi:10.1175/1520-0442(1995)008<1544:Taoafa >2.0.Co;2, 1995.

Dambrine, E., Dupouey, J. L., Laut, L., Humbert, L., Thinon, M., Beaufils, T., and Richard, H.: Present forest biodiversity patterns in France related to former Roman agriculture, Ecology, 88, 1430-1439, doi:10.1890/05-1314, 2007.

Davidson, E. A. and Ackerman, I. L.: Changes in soil carbon inventories following cultivation of previously untilled soils, Biogeochemistry, 20, 161-193, doi:10.1007/Bf00000786, 1993.

Dean, R., Ellis, J. E., Rice, R. W., and Bement, R. E.: Nutrient removal by cattle from a shortgrass prairie, J. Appl. Ecol., 12, 2529, doi:10.2307/2401715, 1975.

de Noblet-Ducoudre, N., Boisier, J. P., Pitman, A., Bonan, G. B., Brovkin, V., Cruz, F., Delire, C., Gayler, V., van den Hurk, B. J. J. M., Lawrence, P. J., van der Molen, M. K., Muller, C., Reick, C. H., Strengers, B. J., and Voldoire, A.: Determining robust impacts of land-use-induced land cover changes on surface climate over North America and Eurasia: Results from the first set of LUCID experiments, J. Climate, 25, 3261-3281, doi:10.1175/JcliD-11-00338.1, 2012.

Don, A., Schumacher, J., and Freibauer, A.: Impact of tropical landuse change on soil organic carbon stocks - a meta-analysis, Global Change Biol., 17, 1658-1670, doi:10.1111/j.13652486.2010.02336.x, 2011.

Dupouey, J. L., Dambrine, E., Laffite, J. D., and Moares, C.: Irreversible impact of past land use on forest soils and biodiversity, Ecology, 83, 2978-2984, doi:10.2307/3071833, 2002.

Eltahir, E. A. B. and Bras, R. L.: Precipitation recycling, Rev. Geophys., 34, 367-378, doi:10.1029/96rg01927, 1996.

Falkengren-Grerup, U., ten Brink, D. J., and Brunet, J.: Land use effects on soil N, P, C and pH persist over 40-80 years of forest growth on agricultural soils, Forest Ecol. Manage., 225, 74-81, doi:10.1016/j.foreco.2005.12.027, 2006.

Fichtner, A., von Oheimb, G., Hardtle, W., Wilken, C., and Gutknecht, J. L. M.: Effects of anthropogenic disturbances on soil microbial communities in oak forests persist for more than 100 years, Soil Biol. Biochem., 70, 79-87, doi:10.1016/j.soilbio.2013.12.015, 2014.

Foley, J. A., Costa, M. H., Delire, C., Ramankutty, N., and Snyder, P.: Green surprise? How terrestrial ecosystems 
could affect earth's climate, Front. Ecol. Environ., 1, 38-44, doi:10.2307/3867963, 2003.

Foote, R. L. and Grogan, P.: Soil carbon accumulation during temperate forest succession on abandoned low productivity agricultural lands, Ecosystems, 13, 795-812, doi:10.1007/s10021-0109355-0, 2010.

Foster, D., Swanson, F., Aber, J., Burke, I., Brokaw, N., Tilman, D., and Knapp, A.: The importance of land-use legacies to ecology and conservation, Bioscience, 53, 77-88, doi:10.1641/00063568(2003)053[0077:Tiolul]2.0.Co;2, 2003.

Fuchs, R., Herold, M., Verburg, P. H., Clevers, J. G. P. W., and Eberle, J.: Gross changes in reconstructions of historic land cover/use for Europe between 1900 and 2010, Global Change Biol., 21, 299-313, doi:10.1111/gcb.12714, 2015.

Fujisaki, K., Perrin, A. S., Desjardins, T., Bernoux, M., Balbino, L. C., and Brossard, M.: From forest to cropland and pasture systems: A critical review of soil organic carbon stocks changes in Amazonia, Global Change Biol., 21, 2773-2786, doi:10.1111/gcb.12906, 2015.

Giambelluca, T. W.: Hydrology of altered tropical forest, Hydrol. Process., 16, 1665-1669, doi:10.1002/Hyp.5021, 2002.

Guariguata, M. R. and Ostertag, R.: Neotropical secondary forest succession: Changes in structural and functional characteristics, Forest Ecol. Manage., 148, 185-206, doi:10.1016/S03781127(00)00535-1, 2001.

Guo, L. B. and Gifford, R. M.: Soil carbon stocks and land use change: A meta analysis, Global Change Biol., 8, 345-360, doi:10.1046/j.1354-1013.2002.00486.x, 2002.

Haxeltine, A. and Prentice, I. C.: BIOME3: An equilibrium terrestrial biosphere model based on ecophysiological constraints, resource availability, and competition among plant functional types, Global Biogeochem. Cy., 10, 693-709, doi:10.1029/96gb02344, 1996.

Hickler, T., Smith, B., Sykes, M. T., Davis, M. B., Sugita, S., and Walker, K.: Using a generalized vegetation model to simulate vegetation dynamics in northeastern USA, Ecology, 85, 519530, doi:10.1890/02-0344, 2004.

Hobbs, R. J., Higgs, E., and Harris, J. A.: Novel ecosystems: Implications for conservation and restoration, Trends Ecol. Evol., 24, 599-605, doi:10.1016/j.tree.2009.05.012, 2009.

Hooker, T. D. and Compton, J. E.: Forest ecosystem carbon and nitrogen accumulation during the first century after agricultural abandonment, Ecol. Appl., 13, 299-313, doi:10.1890/10510761(2003)013[0299:Fecana]2.0.Co;2, 2003.

Hughes, R. F., Kauffman, J. B., and Jaramillo, V. J.: Biomass, carbon, and nutrient dynamics of secondary forests in a humid tropical region of Mexico, Ecology, 80, 1892-1907, 1999.

Hurtt, G. C., Chini, L. P., Frolking, S., Betts, R. A., Feddema, J., Fischer, G., Fisk, J. P., Hibbard, K., Houghton, R. A., Janetos, A., Jones, C. D., Kindermann, G., Kinoshita, T., Goldewijk, K. K., Riahi, K., Shevliakova, E., Smith, S., Stehfest, E., Thomson, A., Thornton, P., van Vuuren, D. P., and Wang, Y. P.: Harmonization of land-use scenarios for the period 1500-2100: 600 years of global gridded annual land-use transitions, wood harvest, and resulting secondary lands, Climatic Change, 109, 117-161, doi:10.1007/s10584-011-0153-2, 2011.

Jones, H. P. and Schmitz, O. J.: Rapid recovery of damaged ecosystems, Plos One, 4, e5653, doi:10.1371/journal.pone.0005653, 2009.
Kauffman, J. B., Hughes, R. F., and Heider, C.: Carbon pool and biomass dynamics associated with deforestation, land use, and agricultural abandonment in the Neotropics, Ecol. Appl., 19, 1211-1222, doi:10.1890/08-1696.1, 2009.

Kesselmeier, J. and Staudt, M.: Biogenic volatile organic compounds (VOC): An overview on emission, physiology and ecology, J. Atmos. Chem., 33, 23-88, doi:10.1023/A:1006127516791, 1999.

Knops, J. M. H. and Tilman, D.: Dynamics of soil nitrogen and carbon accumulation for 61 years after agricultural abandonment, Ecology, 81, 88-98, doi:10.1890/00129658(2000)081[0088:Dosnac]2.0.Co;2, 2000.

Laganiere, J., Angers, D. A., and Pare, D.: Carbon accumulation in agricultural soils after afforestation: A metaanalysis, Global Change Biol., 16, 439-453, doi:10.1111/j.13652486.2009.01930.x, 2010.

Lamarque, J. F., Dentener, F., McConnell, J., Ro, C. U., Shaw, M., Vet, R., Bergmann, D., Cameron-Smith, P., Dalsoren, S., Doherty, R., Faluvegi, G., Ghan, S. J., Josse, B., Lee, Y. H., MacKenzie, I. A., Plummer, D., Shindell, D. T., Skeie, R. B., Stevenson, D. S., Strode, S., Zeng, G., Curran, M., Dahl-Jensen, D., Das, S., Fritzsche, D., and Nolan, M.: Multi-model mean nitrogen and sulfur deposition from the Atmospheric Chemistry and Climate Model Intercomparison Project (ACCMIP): Evaluation of historical and projected future changes, Atmos. Chem. Phys., 13, 7997-8018, doi:10.5194/acp-13-7997-2013, 2013.

Lauenroth, W. K. and Milchunas, D. G.: Shortgrass steppe, in: Natural grasslands: Introduction and western hemisphere, edited by: Coupland, R. T., Elsevier Science, Amsterdam, 1992.

Lesschen, J. P., Cammeraat, L. H., Kooijman, A. M., and van Wesemael, B.: Development of spatial heterogeneity in vegetation and soil properties after land abandonment in a semi-arid ecosystem, J. Arid Environ., 72, 2082-2092, doi:10.1016/j.jaridenv.2008.06.006, 2008.

Li, D. J., Niu, S. L., and Luo, Y. Q.: Global patterns of the dynamics of soil carbon and nitrogen stocks following afforestation: A meta-analysis, New Phytol., 195, 172-181, doi:10.1111/j.14698137.2012.04150.x, 2012.

Lindeskog, M., Arneth, A., Bondeau, A., Waha, K., Seaquist, J., Olin, S., and Smith, B.: Implications of accounting for land use in simulations of ecosystem carbon cycling in Africa, Earth Syst. Dynam., 4, 385-407, doi:10.5194/esd-4-385-2013, 2013.

MacDonald, G. K., Bennett, E. M., and Taranu, Z. E.: The influence of time, soil characteristics, and land-use history on soil phosphorus legacies: A global meta-analysis, Global Change Biol., 18, 1904-1917, doi:10.1111/j.1365-2486.2012.02653.x, 2012.

Martin, P., Jung, M., Brearley, F. Q., Ribbons, R. R., Lines, E. R., and Jacob, A. L.: Can we set a global threshold age to define mature forests?, Peer J., 4, E1595, doi:10.7717/Peerj.1595, 2016.

McLauchlan, K.: The nature and longevity of agricultural impacts on soil carbon and nutrients: A review, Ecosystems, 9, 13641382, doi:10.1007/s10021-005-0135-1, 2006.

McSherry, M. E. and Ritchie, M. E.: Effects of grazing on grassland soil carbon: A global review, Global Change Biol., 19, 13471357, doi:10.1111/gcb.12144, 2013.

Milchunas, D. G. and Lauenroth, W. K.: Quantitative effects of grazing on vegetation and soils over a global range of environments, Ecol. Monogr., 63, 327-366, doi:10.2307/2937150, 1993. 
Miller, P. A., Giesecke, T., Hickler, T., Bradshaw, R. H. W., Smith, B., Seppa, H., Valdes, P. J., and Sykes, M. T.: Exploring climatic and biotic controls on Holocene vegetation change in Fennoscandia, J. Ecol., 96, 247-259, doi:10.1111/j.13652745.2007.01342.x, 2008.

Moran, E. F., Brondizio, E. S., Tucker, J. M., da Silva-Forsberg, M. C., McCracken, S., and Falesi, I.: Effects of soil fertility and land-use on forest succession in Amazonia, Forest Ecol. Manage., 139, 93-108, doi:10.1016/S0378-1127(99)00337-0, 2000.

Murty, D., Kirschbaum, M. U. F., McMurtrie, R. E., and McGilvray, A.: Does conversion of forest to agricultural land change soil carbon and nitrogen? A review of the literature, Global Change Biol., 8, 105-123, doi:10.1046/j.1354-1013.2001.00459.x, 2002.

Norden, N., Angarita, H. A., Bongers, F., Martinez-Ramos, M., Granzow-de la Cerda, I., Breugel, M., Lebrija-Trejos, E., Meave, J. A., Vandermeer, J., Williamson, G. B., Finegan, B., Mesquita, R., and Chazdon, R. L.: Successional d ynamics in Neotropical forests are as uncertain as they are predictable, P. Natl. Acad. Sci. USA, 112, 8013-8018, doi:10.1073/pnas.1500403112, 2015.

Pan, Y. D., Birdsey, R. A., Fang, J. Y., Houghton, R., Kauppi, P. E., Kurz, W. A., Phillips, O. L., Shvidenko, A., Lewis, S. L., Canadell, J. G., Ciais, P., Jackson, R. B., Pacala, S. W., McGuire, A. D., Piao, S. L., Rautiainen, A., Sitch, S., and Hayes, D.: A large and persistent carbon sink in the world's forests, Science, 333, 988-993, doi:10.1126/science.1201609, 2011.

Paul, K. I., Polglase, P. J., Nyakuengama, J. G., and Khanna, P. K.: Change in soil carbon following afforestation, Forest Ecol. Manage., 168, 241-257, doi:10.1016/S0378-1127(01)00740-X, 2002.

Peng, S. S., Piao, S. L., Zeng, Z. Z., Ciais, P., Zhou, L. M., Li, L. Z. X., Myneni, R. B., Yin, Y., and Zeng, H.: Afforestation in China cools local land surface temperature, P. Natl. Acad. Sci. USA, 111, 2915-2919, doi:10.1073/pnas.1315126111, 2014.

Penuelas, J. and Staudt, M.: BVOCS and global change, Trends Plant Sci., 15, 133-144, doi:10.1016/j.tplants.2009.12.005, 2010.

Pielke, R. A., Pitman, A., Niyogi, D., Mahmood, R., McAlpine, C., Hossain, F., Goldewijk, K. K., Nair, U., Betts, R., Fall, S., Reichstein, M., Kabat, P., and de Noblet, N.: Land use/land cover changes and climate: Modeling analysis and observational evidence, Wires Clim. Change, 2, 828-850, doi:10.1002/wcc.144, 2011.

Poeplau, C., Don, A., Vesterdal, L., Leifeld, J., Van Wesemael, B., Schumacher, J., and Gensior, A.: Temporal dynamics of soil organic carbon after land-use change in the temperate zone - carbon response functions as a model approach, Global Change Biol., 17, 2415-2427, doi:10.1111/j.1365-2486.2011.02408.x, 2011.

Post, W. M. and Kwon, K. C.: Soil carbon sequestration and landuse change: Processes and potential, Global Change Biol., 6, 317-327, doi:10.1046/j.1365-2486.2000.00308.x, 2000.

Potter, K. N., Torbert, H. A., Johnson, H. B., and Tischler, C. R.: Carbon storage after long-term grass establishment on degraded soils, Soil Sci., 164, 718-725, doi:10.1097/00010694199910000-00002, 1999.

Potter, P., Ramankutty, N., Bennett, E. M., and Donner, S. D.: Characterizing the spatial patterns of global fertilizer application and manure production, Earth Interact., 14, 1-22, doi:10.1175/2009ei288.1, 2010.
Poulton, P. R., Pye, E., Hargreaves, P. R., and Jenkinson, D. S.: Accumulation of carbon and nitrogen by old arable land reverting to woodland, Global Change Biol., 9, 942-955, doi:10.1046/j.1365-2486.2003.00633.x, 2003.

Pugh, T. A. M., Arneth, A., Olin, S., Ahlstrom, A., Bayer, A. D., Goldewijk, K. K., Lindeskog, M., and Schurgers, G.: Simulated carbon emissions from land-use change are substantially enhanced by accounting for agricultural management, Environ. Res. Lett., 10, 124008, doi:10.1088/1748-9326/10/12/124008, 2015.

Queiroz, C., Beilin, R., Folke, C., and Lindborg, R.: Farmland abandonment: Threat or opportunity for biodiversity conservation? A global review, Front. Ecol. Environ., 12, 288-296, doi:10.1890/120348, 2014.

Randriamalala, J. R., Herve, D., Randriamboavonjy, J. C., and Carriere, S. M.: Effects of tillage regime, cropping duration and fallow age on diversity and structure of secondary vegetation in Madagascar, Agr. Ecosyst. Environ., 155, 182-193, doi:10.1016/j.agee.2012.03.020, 2012.

Richter, D. D., Markewitz, D., Heine, P. R., Jin, V., Raikes, J., Tian, K., and Wells, C. G.: Legacies of agriculture and forest regrowth in the nitrogen of old-field soils, Forest Ecol. Manage., 138, 233 248, doi:10.1016/S0378-1127(00)00399-6, 2000.

Saldarriaga, J. G., West, D. C., Tharp, M. L., and Uhl, C.: Long-term chronosequence of forest succession in the upper Rio Negro of Colombia and Venezuela, J. Ecol., 76, 938-958, doi:10.2307/2260625, 1988 .

Scharlemann, J. P. W., Tanner, E. V. J., Hiederer, R., and Kapos, V.: Global soil carbon: Understanding and managing the largest terrestrial carbon pool, Carbon Manage., 5, 81-91, doi:10.4155/Cmt.13.77, 2014.

Schierhorn, F., Muller, D., Beringer, T., Prishchepov, A. V., Kuemmerle, T., and Balmann, A.: Post-Soviet cropland abandonment and carbon sequestration in European Russia, Ukraine, and Belarus, Global Biogeochem. Cy., 27, 1175-1185, doi:10.1002/2013GB004654, 2013.

Shevliakova, E., Pacala, S. W., Malyshev, S., Hurtt, G. C., Milly, P. C. D., Caspersen, J. P., Sentman, L. T., Fisk, J. P., Wirth, C., and Crevoisier, C.: Carbon cycling under 300 years of land use change: Importance of the secondary vegetation sink, Global Biogeochem. Cy., 23, GB2022, doi:10.1029/2007gb003176, 2009.

Silver, W. L., Ostertag, R., and Lugo, A. E.: The potential for carbon sequestration through reforestation of abandoned tropical agricultural and pasture lands, Restor. Ecol., 8, 394-407, doi:10.1046/j.1526-100x.2000.80054.x, 2000.

Smith, B., Warlind, D., Arneth, A., Hickler, T., Leadley, P., Siltberg, J., and Zaehle, S.: Implications of incorporating N cycling and $\mathrm{N}$ limitations on primary production in an individualbased dynamic vegetation model, Biogeosciences, 11, 2027 2054, doi:10.5194/bg-11-2027-2014, 2014.

Smith, P., Andren, O., Karlsson, T., Perala, P., Regina, K., Rounsevell, M., and van Wesemael, B.: Carbon sequestration potential in European croplands has been overestimated, Global Change Biol., 11, 2153-2163, doi:10.1111/j.1365-2486.2005.01052.x, 2005.

Stocker, B. D., Feissli, F., Strassmann, K. M., Spahni, R., and Joos, F.: Past and future carbon fluxes from land use change, 
shifting cultivation and wood harvest, Tellus B, 66, 23188, doi:10.3402/Tellusb.V66.23188, 2014.

Suding, K. N., Gross, K. L., and Houseman, G. R.: Alternative states and positive feedbacks in restoration ecology, Trends Ecol. Evol., 19, 46-53, doi:10.1016/j.tree.2003.10.005, 2004.

Uhl, C., Buschbacher, R., and Serrao, E. A. S.: Abandoned pastures in Eastern Amazonia. 1. Patterns of plant succession, J. Ecol., 76, 663-681, doi:10.2307/2260566, 1988.

Vellend, M.: Parallel effects of land-use history on species diversity and genetic diversity of forest herbs, Ecology, 85, 3043-3055, doi:10.1890/04-0435, 2004.

Wall, A. and Hytonen, J.: Soil fertility of afforested arable land compared to continuously, Plant Soil, 275, 247-260, doi:10.1007/s11104-005-1869-4, 2005.
Wandelli, E. V. and Fearnside, P. M.: Secondary vegetation in central Amazonia: Land-use history effects on aboveground biomass, Forest Ecol. Manage., 347, 140-148, doi:10.1016/j.foreco.2015.03.020, 2015.

Wilkenskjeld, S., Kloster, S., Pongratz, J., Raddatz, T., and Reick, C. H.: Comparing the influence of net and gross anthropogenic land-use and land-cover changes on the carbon cycle in the MPIESM, Biogeosciences, 11, 4817-4828, doi:10.5194/bg-11-48172014, 2014.

Willis, K. J., Gillson, L., and Brncic, T. M.: How "virgin" is virgin rainforest?, Science, 304, 402-403, doi:10.1126/science.1093991, 2004.

Wu, S., Mickley, L. J., Kaplan, J. O., and Jacob, D. J.: Impacts of changes in land use and land cover on atmospheric chemistry and air quality over the 21 st century, Atmos Chem Phys, 12, 15971609, doi:10.5194/acp-12-1597-2012, 2012. 